\title{
3
}

\section{Linguistic and territorial organisation: The Wik classical system}

\author{
Peter Sutton
}

\section{Totemic clans}

In somewhat simplified terms, the Wik patrilineal descent group is the elemental linguistic and country-holding unit of classical times and on into at least the 1970s. It is a set of people formed on a principle of shared genealogical origins. Until recent decades, the descent principle was simply patrilineal. ${ }^{1}$ That is, a person at birth acquired a primary landed estate, its named dialect, a set of clan totems, a set of clan totemic names (differing according to gender), plus a set of totemic names that they may use for their own dogs (again differing by gender). The default rule was that these came to a newborn child through its father and father's father. A catalogue of Wik totemic clans including their dialects and totemic names is provided in Appendix 1. A catalogue of their estates is provided as Appendix 2.

In most cases, this clan identity was also that of a person's father's father, and his father, and their siblings both female and male, back through time to the earliest memories, although there have been some principled exceptions to this pattern, which are discussed in Appendix 1: Clan list.

1 The shift to a principle of cognatic descent is discussed later. 
Not only is this patrilineal pattern what people specify from their memory, but it can also be attested in many cases from the written record. A comparison of the ethnographies of the 1970s-90s with that of Ursula McConnel in 1927-28, on the relationship between clan identities and the location of estates held by those clans, is available from Appendix 1. This material, as well as the field notes of Donald Thomson made in the region in 1933, provides ample evidence of relative stability in the system of relationships between particular patriclans, particular named dialects, particular totems, and particular estates. ${ }^{2}$

This kind of patrilineal continuity is not merely the consequence of what anthropologists call serial patrifiliation-that is, the cumulative result of an ascending series of one-off filiations to fathers. Wik culture actually conceives of the pattern as continuous, and symbolises the nature of this descent, for example, by the use of the term for 'father's father' (puul) as the basis for the term meaning 'patrilineal totem' in several of the languages distinctive to the region, including the lingua franca WikMungkan. The common Wik-Way term for patrilineal totem is olay, which in Linngithigh, at least, literally also means 'father's father' (Hale 1997a). In Wik-Mungkan, one's aak puul is one's patrilineal estate (Kilham et al. 1986:5), puul-way is 'patrilineal totem' (ibid.:195; McConnel 1930a:181-205; Thomson 1946), and both are based historically on the ancient proto-Paman root * puula 'father's father' (Hale 1976c:58), which does not often occur alone in Wik languages but is embedded in the WikMungkan compound puul-wuut 'father's father', wuut literally meaning 'old man' and in aak puul 'father's father country'. In southern Wik languages the equivalent of puul-way is kam-waya (von Sturmer 1978: Chapter 10). This kam is most likely to derive from proto-Paman ${ }^{*} k a m i$ 'parallel grandparent, i.e. father's father and mother's mother'. ${ }^{4}$

2 For some of the more obvious evidence of such continuity see Appendix 1, Clans 31, 33, 34, 36 and 39 for a sample of matches between McConnel's 1929 data and our own dating from the 1970s to the 1990 s.

3 In the upper Archer dialect of Clan 75 the equivalent is puul-ay. The evidence thus suggests that Wik-Way olay 'totem' may be etymologically the same compound, hence ol-ay would derive historically from something like *puul-way. The pronunciation pulway has also been recorded in Wik-Mungkan.

4 While kam means 'mother's mother' in contemporary Kugu Ngancharra, von Sturmer (1978:321) argues, successfully in my view, that its historical derivation is from a term meaning 'parallel grandparent' (i.e. both MM and FF), here the reference being to FF (father's father). Note also that kami means 'parallel grandparent' (FF/MM) in Cape York Peninsula languages Yintyingka, Guugu-Yimidhirr, and Kuku-Yalanji. Cognates kame and kemiy have the same FF/MM meaning in CYP languages Pakanh and Wik-Ngathan respectively. 
In Wik-Ngathan the term for 'totem' is kooenhiy, literally 'sibling'. An animal totem is minh kooenhiy 'meat sibling', and an edible plant totem is may kooenhiy 'vegetable sibling'. This use of the sibling term presumably reflects the widespread Aboriginal emphasis on the structural equivalence of grandkin and siblings, although it may also be a reference to the father's father's father's father (FFFF) and his brothers (and probably sisters), who in these and many other Aboriginal languages are classified as one's siblings.

While a classical Wik clan principally recruits by descent, not all of its members in every case will know of or claim common descent from a single remembered apical ancestor. Some of the clans do consist of people descended from a single remembered common ancestor, but many do not. As elsewhere in Australia, this does not of itself compromise the definition of the clan as a group recruiting essentially on a principle of descent.

It is thus quite common for a clan to consist of two or more genealogical segments. While there is a high degree of agreement between the relevant group members as to the relationships of genealogical connection between living or recently deceased people, the further back in time one goes, the more likely one is to find that memories of upper generation links between individuals differ. Some may say, for example, that two long deceased members of the same clan were full siblings, while others may say they were only parallel cousins. Incorporation of a foreign patriline into a clan has occurred in modern times. ${ }^{5}$

Clan segments may be ranked, such that the relative seniority of their founding members is recognised. This is a pattern reported for the southern Wik area, among the Kugu Ngancharra (von Sturmer 1978: 337-39). The ranking is made manifest, in particular, by the selection of different 'Big Names' (based on clan totems) for different siblings. It is also possible that different segments within a clan, descended from different siblings, may identify more with one of the clan's totems than another and thus differentiate themselves while holding the same estate. There is not much evidence for this in the northern Wik area, although some fragmentary material supports the likelihood that it occurs there to some

5 In the case of Estate 3 (see Appendix 2), there was in the early twentieth century a formal incorporation of the Bowenda patriline into Clan 3. The Bowendas had come to Aurukun from the Doomadgee region, far away, headed by King Bowenda. When he died, his widow Lily married Moses Ampeybegan of Clan 3, and her children with Bowenda were taken by Moses as his children also and thus became members of Clan 3 . 
extent: descendants of the Wikmunea branch of Clan 6 are known as Nguungk Piith ('Grassbird Clan Dialect'), while members of the Pumpkin segment of the same clan are known as Nguungk Chiiynchiiyn ('Bushrat Clan Dialect'). ${ }^{6}$

These dialect identifiers, like a large number of others, use a principal totem of the clan (sometimes, a clan segment) as the base of the dialect names (here, Grassbird and Bushrat). In Wik ideology, each patriclan has its own dialect, given to it at the beginning of the world. ${ }^{7}$ However, several clans also share a different kind of dialect name, based not on a totem but on one of its distinctive lexical features, such as the names that translate as 'Language Go' (Wik-Me'enh, Kugu Mu'inh, Wik-liyanh and so on) and 'Language Eat' (Wik-Mungkan). These are the collective linguistic identities commonly referred to as 'tribes', 'dialectal tribes', or 'language groups', in the Australian anthropological literature. More detail on this topic is given in Chapter 5, along with a catalogue of linguistic varieties of the Wik Region.

Not only clans but particular clan segments may emphasise as major totems some phenomenon with which another clan group also identifies. Different groups may use this symbolic sharing on occasion to express a sense of unity among themselves, as when members of a Brolgaassociated clan from the Wik area emphasise their amity with another Brolga clan from the Thaayorre language area south of Edward River. People of the same totem, regardless of clan membership, may use those endearing forms of mutual address that stress the quality of 'having the same name' (e.g. ngalamp 'namesake', from ngal 'we two' and nhamp 'name'). In general, however, merely having the same totem as another person does not of itself reach into the heart of how political relationships between groups are conducted.

In summary, a classical Wik clan is a small-scale structural (descent-based) country-holding unit, a unit of totemic identity, and the primary dialectal unit. It is not a residential unit, a household, a camp, or any other kind of economic or physically aggregating set. Nor is it the exclusive province within which rights and interests in country are generated and transmitted, although it is the primary domain and entry point for enjoying country

6 David Martin, pers. comm., 1997.

7 A detailed account of an example of the mythological genesis of Wik languages, provided by Noel Peemuggina (Clan 6), is in Sutton (1997b). 
rights in the classical system. Its members typically have rightful interests in the estates of clans other than their own, such as those of their nonpatrilineal forebears (mother's father's patriline especially) and their affines (in simple terms, their spouses and in-laws).

\section{Households, camps, and bands}

A bush camp or band, by contrast, ${ }^{8}$ was an on-the-ground residential, hunting or other action group. Camps had no formal names, but could be referred to, using the name of the dominant member of the camp, as 'So-and-so's mob'.

As far as we can tell, classical Wik bands, like others well documented elsewhere, were in the past made up usually of individual members drawn from several or even many clans at any one time, and were thus also polyglot groups. Clans were, as they mostly are now, normally out-marrying, so even at the core level of the married couple, at least two clans would normally be represented in any camp in which there was such a couple. A widowed mother present in the camp or household of her married son or daughter - a rather typical arrangement—would frequently be from a third clan. Where the camp had as its core two sisters and their husbands, the husbands would often be from two different clans also. This means that members of a single clan would normally be found scattered through a number of bands at any one time. Conversely, a camp of 10 or 20 people would typically contain people drawn from between several and perhaps a dozen different clans. ${ }^{9}$ Wik people do not attribute proprietorial interests in land and waters to bands, or their modern equivalents of households, holiday camps, carloads, outstations, hunting parties and so on.

Band sizes are hard to reconstruct for the period prior to the gradual settlement of Wik Region people at missions, towns and pastoral stations. They would have varied widely from the small, atomised pattern of the

8 Since the debate between L.R. Hiatt $(1962,1966)$ and W.E.H. Stanner (1965) over Aboriginal local organisation, the use of the earlier term 'horde' for an Aboriginal residential group has all but disappeared. This term, as used by A.R. Radcliffe-Brown (1930-31), tended to conflate the descentbased land-holding group with the land-utilising camp group. Anthropological terminology has basically settled for naming the former the 'clan' and the latter the 'band'. A critique of the term 'clan' by Ian Keen $(1994,1995,1997)$, particularly as it has been applied in north-east Arnhem Land, has not persuaded us to abandon its use in the Wik context.

9 This can be seen in the lists of names of those present at specific events in the bush recorded during site mapping (see Sutton et al. 1990), and, for more recent times, in the compositions of outstations, hunting parties, households in townships, and so on. 
wet season, when people were isolated in small groups, and more or less immobilised and dwelling in waterproof shelters, to the large ceremonial congregations of the late dry season. ${ }^{10}$ One tends to think of bands as small foraging groups, averaging, say, 25 people, but larger semi-nomadic camps have been recorded elsewhere, at least, and have been called 'communities' by some anthropologists (see section below, this chapter, Communities). Not only did bands change size, they also changed composition, certainly seasonally, probably from week to week, and probably on occasion from day to day.

\subsubsection{Report on Aurukun mission:}

Particulars of native camps:

- Aurukun mission - 56 men, 53 women, 28 boys, 24 girls

- Mouth of Love River, $20 \mathrm{~m}$ south of Archer River - 25 men, 13 women, 2 boys, 1 girl

- Ootuk [Uthuk Aweyn, Big Lake], big swamp on way to Kendall River 5 men, 5 women, 1 boy

- Yonko [Yu'engk] district [Cape Keerweer area] between Ootuk and Kendall - 43 men, 19 women, 3 boys, 5 girls

- Knox Creek district north of Kendall - 8 men, 19 women, 9 boys, 6 girls

- Mymungkum [Maymangkem] people inland from Yonko [Maymangkem probably refers to Kencherrang area in this case] -13 men, 5 women, 5 boys, 2 girls

- Ornyawa [Oony-aw] people behind Mymungkum [north-east Kirke system] - 8 men, 12 women, children in mission

- Ti-tree people south of Mymungkum down to Kendall - 4 men, 4 women, 3 girls

- Warkum [Waakemem] people inland around Love River - 5 men, 4 women, 2 boys, 2 girls

- Wik-ngartona [Wik-Ngathan] people Kendall mouth - 19 men, 12 women, 7 boys, 5 girls

- Wik-ngenchera [i.e. Kugu Ngancharra] people from Kendall mouth to Holroyd mouth - 25 men, 33 women 8 boys, 9 girls

- Patchim [Pechem, 'From Savannah Woodland'] people inland from Kendall to Holroyd - 12 men, 17 women, 2 boys 4 girls

TOTAL: 232 men, 195 women, 67 boys, 61 girls ${ }^{11}$

10 For details of seasonal site use by Wik bands, see Thomson (1939), and Sutton (2010).

11 These last figures total 555. However, MacKenzie's details above indicate 161 at Aurukun plus 
It is fortunate that in the Wik case there are some demographic details available for people who had not as yet settled at Aurukun Mission. William MacKenzie, then superintendent of Aurukun, recorded the following figures for certain sets of people occupying the bush south of the mission in 1928, while he was on an overland field visit to the Holroyd River from Aurukun:

These numbers, with the exception of the mission figures, are based on the numbers counted while on patrol this year down to the Holroyd River. These numbers are not complete, for we did not see some of the old people nor all the children, especially down near the Holroyd, where the people were very shy.

Three years later MacKenzie reported:

NATIVE CAMPS: North and south of the Archer the people live mainly in the Mission, only going out camping at intervals ... There are native camps at each of the following places, Yonko [Yu'engk, Cape Keerweer], Errimunka [Eeremangk = Knox River], Kendall River, King Creek and Holroyd River on the coast, while inland the Mymunkum ${ }^{12}$ [eastern Kirke River area], Ornyawa [north-east Kirke system], Ti-tree, and Patchim [upper Holroyd] tribes have their camps. None of these camps are in a fixed locality, nor are the numbers always the same; the people sometimes come into large camps more especially when there is a good food supply and plenty of water, and again splitting up into family groups as the large swamps with the lilies and panjees [edible roots of a swamp grass] get eaten out. Approximate numbers as follows:

YONKO: 20 males, 18 females, 5 children

ERRIMUNKA: 15 males, 14 females, 2 children

KENDALL: 25 males, 30 females, 10 children

HOLROYD: 30 males, 35 females, 15 children

MYMUNKYUM: 15 males, 13 females, 3 children

ORNYAWA: 2 males, 3 females

TI-TREE: 15 males, 12 females, 4 children

12 Our informants in the 1970s referred to Maymangkem as an environmental 'nickname' for people from the Ti-Tree area, i.e. the eastern tributaries of the Kirke system. Roughly translated it means 'From Plentiful Food Area' and is not a linguistic title. Since the figures here for 'Mymunkum' and 'Ti-tree' are practically identical, MacKenzie may have taken the same figures twice under different names. On the other hand, the earlier report suggests Maymangkem, in MacKenzie’s usage, referred to people concentrated about the Kencherrang area on the middle Kirke, downstream from Ti-tree. In 1960, MacKenzie gave Tindale the term 'Mimungkum' for the Ti-Tree group (Tindale 1974:181). 
PATCHIM: 10 males, 8 females, 3 children

CONDITIONS: means of subsistence, native food, game fish, and roots, wild honey. There was no distress from lack of food.

[William MacKenzie, Aurukun, to Chief Protector of Aboriginals, 1931.]

Naturally these numbers are overall well down compared with what they might have been a century earlier, due to the experience of epidemics of the kind described by elder Jack Spear Karntin in the film Familiar Places (1980). Unlike so many other Aboriginal peoples and some inland Wik people from the pastoral frontier, these particular groups referred to by MacKenzie did not suffer massacres by colonists and native police. The number of children in the more northerly camps in MacKenzie's reports would have been further reduced by the 1930s because of the influence of the mission, which by this time had reached down to about the Knox ('Errimunka') in its gradual southward extension. As mission influence spread, increasing numbers of bush children were taken to Aurukun where they lived in dormitories, leaving the bush camps with few children. In general, the closer to Aurukun, the smaller the numbers in these inter-War residential aggregates. Overall figures are: children 45, women 133, men 132 (total 310). The sub-regional aggregates of bush people recorded in these two instances by MacKenzie here had an average size of 38.75 persons, but the actual camp sizes within this domain set were variable, according to MacKenzie: 'None of these camps are in a fixed locality, nor are the numbers always the same'.

If each of these entries by MacKenzie were descriptions of single aggregated camps, the band figures for bush camps south of Aurukun in the dry seasons of 1928 and 1931 would be as set out in Table 3.1.

Table 3.1: Bush camp census data 1928 and 1931

\begin{tabular}{|l|c|c|}
\hline District & Head count 1928 & Head count 1931 \\
\hline Lower Love River & 41 & not listed \\
\hline Ootuk & 11 & not listed \\
\hline Yonko & 70 & 43 \\
\hline Knox Creek & 42 & 31 \\
\hline Mymungkum & 25 & 31 \\
\hline Ornyawa & 20 & 5 \\
\hline Ti-tree & 11 & 31 \\
\hline
\end{tabular}




\begin{tabular}{|l|c|c|}
\hline District & Head count 1928 & Head count 1931 \\
\hline Warkum & 13 & not listed \\
\hline Kendall mouth & 43 & 43 \\
\hline Wik-ngenchera & 75 & 80 \\
\hline Patchim & 35 & 21 \\
\hline TOTALS & $\mathbf{3 8 6}$ & $\mathbf{2 8 5}$ \\
\hline
\end{tabular}

These figures, while valuable and useful, are based on group labels that are not fully comparable. That is, some of these area names refer in English to river systems (e.g. Kendall River, Holroyd River), some to lower river systems called after a main site near their mouths (Yonko, Errimunka), some to major focal inland sites (Warkum, Ootuk, Ornyawa, Ti-tree), some to a language or set of similar languages (Wik-ngartona, Wikngenchera), and some to a social 'nickname' based on the environmental type of country in the clan estates of prominent group residential members (Mymunkum, Patchim). Even if such problems could be erased, however, could such aggregates have been, in the past, the nearest equivalent to 'native title holders'?

It is clear that small bands, larger sub-regional residential aggregates, or their modern equivalents (households, outstations, townships) would be inappropriate 'units' for the process of recognition of native title rights and interests. Households or bands (camps, foraging groups) are notably labile, people being added to them or removed from them at frequent intervals through visiting. Not infrequent cases of conflict also lead to camps or households splitting up for a time. Clans, by contrast, are traditionally viewed by the Wik as enduring corporate entities. They have memberships that change only slowly as births, adoptions and deaths add and remove individual members. The ideal target of the stable corporation is not always met, as in any other society. Clan composition is from time to time disputed. Sets of people (branches, sub-clans) are sometimes added through incorporations and amalgamations, or deleted through clan fission. More importantly, in this context, Wik people conceive of primary rights and interests in country as arising in a privileged way from an essential relationship of identity with, and descent from, one's ancestors, and thus from a higher law than mere human whim. In essence their tenurial system is understood to be not voluntaristic but lawgoverned. The presence of a person in a land-using residential group is, 
by contrast, very much a matter of daily decision-making by individuals and families, and reflects the changing states of interpersonal and interkin-group politics.

The nature of residence on Wik lands has changed historically far more than the nature of Wik land tenure, since the arrival of pastoral stations in the inland in the late nineteenth century, and the arrival of the Moravian (later Presbyterian) Mission at Aurukun on the coast in 1904. The nearest thing to a pre-settlement band in the present-day Wik case is an outstation camp, ${ }^{13}$ a weekend fishing and hunting party, or a township household, although such households, unlike bush camps, are spatially arranged in rows on streets. ${ }^{14}$ David Martin has made detailed analyses of Aurukun household composition in terms of clan memberships, rates of mobility between houses, and age and sex breakdowns, from the 1980s (Martin 1993: Chapter 6). Sutton collected some detailed statistics on clans represented at Wik outstations in the 1970s (Sutton 1978:103; Map 13). In Aak (Sutton et al. 1990) and the more recent mapping data there are details of remembered camp compositions of the distant past. There seem to be no radical differences between the composition of these various residential aggregates, apart from the relative fixity of the housing being used, the largely post-1970s addition of spouses or partners from other communities (e.g. from Weipa, Pormpuraaw, Groote Eylandt or Bentinck Island) with whom contact has been comparatively recent, and the additions of some non-Aboriginal people as permanent members of the community.

There has always been a stronger emphasis on bands in north American native title cases and legislation than in Australia. But such changeable sets of people, with annual foraging patterns that would vary considerably depending on inter-group relations and annual variations in rainfall, for example, would not be suitable for translation into a form of legal recognition of customary tenure in the Australian case. Apart from the fact that they no longer exist in the same form as they did before settlement, bands, it should be remembered, did not have 'estates' of the highly welldefined and durable sort one finds in the case of the Wik clan estates and larger entities such as the riverine groupings, and had considerably variable compositions over any period of weeks or months. Bands did,

13 See Martin and Martin (2016) and Sutton (2016b) for histories of Wik outstations.

14 I have, however, seen a few bush camps set up by bush-reared people where each couple's sleeping place was separated from the next by a small fire, forming a neat row of parallel swags. 
however, have regular ranges of travel and foraging (Stanner 1965), and their members also made occasional very long journeys beyond their usual ranges in order to take part in ceremonies with distant groups.

Bands did not confer primary landed identity on their members, while clans do. (Clans have outlived the semi-nomadic foraging bands of the past.) Bands did not have formal names, although, like the outstations and households of today, they could be referred to by expressions based on the name or other identity of the leading person in the band ('So-and-so's mob'), or by using the clan-cluster nickname that typified the core area in which definitive band members had their estates, or by using the name of some geographic focal point frequented by band members. There is no fixed notion of a band's range, although older Wik people in the 1970s could roughly specify how far they would travel in the bush when young (Chase and Sutton 1981:1838).

Core and dominant members of bands certainly seem to have had more or less regular haunts amounting to what Stanner (1965) termed a 'range'. The usufructuary rights of bands are ultimately grounded in clan tenurial rights in estates, however. A band, as such, did not itself have land-use rights as distinct from those of its members individually. Band membership of itself would not confer usufructuary rights in land or waters. Indeed, the word 'membership' is perhaps too corporate-sounding a term for the phenomenon of living with others.

From the data available it is clear that the typical annual range of a man and his wife or wives and various of their children, with or without other relatives, could greatly exceed the size of any one of the sub-regions named in the MacKenzie census lists for 1928 and 1931. Annual events such as cremation ceremonies, for example, attracted people from widespread parts of the Wik Region to single points (Sutton 1978:149, Sutton et al. 1990).

Clan estates, by contrast, offer specifiable sets of sites that define each estate with some stability, and as structural devices clans themselves offer a relatively well-bounded and commonly stable set of core land holders who share not only an estate but a set of totems, totemic names, a ritual group membership, a dialect affiliation, and so on, which are forms of identity and affiliation that resist instant or cavalier realignments. Among their many other functions, the number and complexity of Wik clan totems, and their often convoluted and archaic expression in 
names and other locutions (see Appendix 1), appear to form a highly conservative and successful barrier against any casual reworking of the tenurial landscape.

A clan's estate and a band's range are also of different epistemological orders, something that is easily obscured when they are paired so habitually. But the former term suggests the corporate and the customary-legal, while the latter is more like behavioural description. Furthermore, the kinds of 'rights and interests' that are focused on matters of landed identity and the proprietary relationship to country are typically those most often associated in many peoples' minds with collective clan (or tribal etc.) membership, while specific rights to use country, such as to catch fish or pick fruit, are typically associated with individual actions. The 'right to forage' is a different kind of right from the right to use possessive first-person pronouns when naming countries, although these rights are intertwined (see section below, this chapter, Households, camps, and bands).

But it is a false dichotomy to pit totemic estate-holding clans against wider categories such as riverine groups or ritual groups ${ }^{15}$ in order to find only one of them to be the 'true locus' of land tenure, as if one had to make an exclusive choice between the two. In the Wik case, however, it was, in the classical system, the clan that held a privileged position in Aboriginal discourse about rights in land, although such rights were not confined to the clan. This places the emphasis on recognition of the persistence of the regional tenure system, within which any particular localised proprietary interests are 'carved out'. The regional tenure system is maintained by the regional Wik population, not estate by estate separately.

\section{Earlier accounts}

The earlier anthropologists' writings are basically compatible with this approach, although they present a simpler picture and concentrate very heavily on the most local level of tenure. Of the Wik people, Donald Thomson wrote (1939:211-12):

15 These terms are explored in more detail below. 
The [patrilineal] clan is the land-owning group; all the members of the clan have hunting rights over the territory of the clan into which they were born. Others, members of the horde ${ }^{16}$ who enter the group by marriage or adoption, never acquire ownership of the territory, but secondarily, the right to hunt over it as members of the occupational group. An individual may be permitted, by the recognition of certain bonds of relationship, i.e. by kinship ties, to hunt in the territories of other clans, for example a man is invariably permitted to hunt in the clan territory of his mother.

Ursula McConnel (1957:xv) said of the Wik people: 'Each ground is owned by a clan, members taking their names from the personal characteristics of the pulwaiya [totemic ancestors] over whose auwa (abode) they preside and perform the required ritual'. As McConnel herself realised, however, this is not strictly true of coastal clans whose members' totemic names refer to totems that in a number of cases do not have corresponding totemic centres ('auwa' sites) in their own estates, but may occur in others' estates or in no known estate at all. In a letter written at Kendall River to A. R. Radcliffe-Brown in 1928 she said:

The totems are all localised $\&$ it is recognised that certain are 'brother' grounds $\wedge$ ie. 'same company' \& others not—marriages take place between the grounds lying nearest to one another, not so often between grounds at a distance. Down here on the sandbeach however, there are names \& totems not localised on these grounds, but on Munkan grounds \& I think this is due to displacement owing to intrusion of people from outside for the physical type here is quite noticeably different from that of the Munkans. (Elkin Papers, University of Sydney Archives, 4/1/57, letter of 3 October 1928)

She published this comment in a revised and expanded form two years later when she again referred to her speculation that 'there may have been a displacement in the coastal region owing to the intrusion of an alien element' (1930a:183 fn.). There is no evidence of any specific 'alien element' of a recent or dramatic kind that would account for such differences, however. Furthermore, two of the coastal clans have estates affiliated with the predominantly inland language Wik-Mungkan (see Estates 12, 20 in Appendix 2) and appear to have been long in situ. The fact that inland

16 'Horde' here refers to the band or camp. 
clan totems were also to be found as the Beings of sites in their estates, while on the coast there was no such regular correspondence, has all the marks of ancient and entrenched practice.

\section{The language of Wik land tenure}

In the Wik languages and in English, people of the Aurukun region will commonly express a possessive relationship between people and particular places or whole land areas by employing the normal genitive/ dative ('oblique') pronouns; hence, in Wik-Ngathan, aak ngathunm 'my country', aak thanent 'their place', nhath ngampunent 'our homeland' and so on. A possessive suffix on nouns conveys a similar relationship of possession (Johnny-ntam aak 'Johnny's country'). The fact that traditional country is not conceived of as a chattel, however, is in part reflected in the fact that kin terms are uninflected for possession in cases such as aak puul (Wik-Mungkan, 'father's father land' [and, usually, by implication, one's own land]), aak kaath-kaal (Wik-Ngathan, 'mother and mothers' brother land'), and aak pepiy (Wik-Ngathan, 'mother's father country').

Places possessed in this sense are also places of origin, whether or not the people concerned were born or had an early phase of residence at the places concerned. This is expressed by the use of ablative suffixes in Wik languages (such as $-m$ ) and the preposition 'from' in English, e.g. Than Eeremangkem (Wik-Ngathan, 'They are from Knox River'), 'Ngampel Yu'engkem' (Wik-Ngathan: 'We are all from the Yu'engk [lower Kirke River] area'); Than Oony-awam (Wik-Mungkan, 'They are from Ornyawa Lagoons country') and so on. The same expressions can, however, also be used of current places of residence ('We are from Aurukun') without any firm implication of customary rights of possession. It is usually recognised that the town site of Aurukun, for example, belongs at the finest-grained level to Estate 29 (see Appendix 2).

People who hold responsibility for country under traditional Aboriginal law are said to be 'looking after' it (kooepeyn, in Wik-Ngathan). This verb has two senses: an intransitive usage, 'to wait', and a transitive usage, 'to be custodian of, look after, supervise'. The Wik-Mungkan verb kuupan has these same two usages (Kilham et al. 1986:80). 
In Cape York Peninsula English, the term 'tribal land' is in common currency as referring to land affiliations based, not purely on residential history, but on inheritance through various principles of Aboriginal customary law. The communal rather than individual emphasis of this notion is partly suggested by the choice of the term 'tribal'. In recent decades the term 'clan' has also come into vogue at Aurukun and is often used to refer to the five rather large ceremonial groupings that have geographic groupings at their base (see section above, this chapter, Regional ceremonial groups, and Map A1.1), and occasionally to outstation groups, or to what I and other anthropologists would call a 'clan' in the technical sense (an estateholding descent group). Context will usually make it clear in what sense the phrase is intended.

These English words may be interpreted as various translations of indigenous terms such as X-punchan (Wik-Mungkan) or X-poencheyn (Wik-Ngathan, Wik-Elken), which are adjectives meaning 'belonging to place X, usually under Aboriginal customary law'. These expressions appear to be based on gerunds derived from intransitive verb stems, which in each case have a root meaning of 'to descend, to go down into' (see Kilham et al. 1986:191; Sutton 1995a:82). This is probably a reference to the fact that the totemic and heroic ancestral Beings who created the landscape's clan estates and their sacred totemic places (aw, Wik-Mungkan; eemoeth, WikNgathan, Wik-Elken etc.; awu in the inland and southern Wik Subgroup languages), thus allocating people to territory, 'went down' into the earth at the site of the totemic centres. Increase rites performed at such places are referred to as 'throwing' (thee'an, most Wik languages) the phenomenon. This is the standard idiom used for digging a hole in the ground such as when unearthing tubers, or for cleaning out an existing well.

In Wik-Ngathan the phrase X-weykanh means 'to belong to X [place]', 'to have X [area] as one's lawful run' (Sutton 1995a:124). Older people's Wik-Mungkan also has the cognate idiom aakan wakan, literally 'to follow a country', meaning 'to come from [place X]' (Kilham et al. 1986:2). In the southern Wik languages pama X-wakanh means literally 'people who frequent $X$ ', the latter verb carrying the primary suggestion of legal occupiers rather than mere inhabitants (von Sturmer 1978:270-71).

Other local terms expressing relations of belonging between people and land are often translated into English as 'countryman', 'owner of the land' or 'boss for the land', and 'full country', 'own country', 'really country', 'company land', and so on. The first set stresses the bond between a set of 
two or more people or groups of people based on common relations to land, and the second set stresses various levels of exclusivity and sharing in possessive relations with land.

The first term, 'countryman', is matched in Wik-Mungkan by aak-kunch ('owner(s) or boss(es) of a certain territory', Kilham et al. 1986:3,76) and in Wik-Ngathan by aak-koenth ('members of clans with adjacent or nearby estates who share country and knowledge and who engage in joint activities such as cremations', Sutton 1978:128).

As explained by von Sturmer (1978:274-78), the English expression 'full country' in the southern Wik Subgroup region translates agu kunyji or 'heartland'. Kunyji in varieties of Kugu Ngancharra is cognate with the expressions kuunch and kooenhiy in other Wik languages, and all three refer to siblings. (These are not the same as kunch and koenth.) Agu kunyji is non-company land normally inherited from the father. Company land, rights in which are also normally inherited from the father, are referred to in Kugu Ngancharra as agu ngalagun. Both company and non-company land in the south are agu pibinam, 'country from father'. In Wik-Mungkan the expression aak puul ('father's father country') is the usual term for country inherited from father/father's father, and is often translated as 'real country' or 'proper country'. These expressions reflect the traditional privileging of patrilineal descent as a primary pathway to membership of land-holding groups in the Wik Region. As explained elsewhere in this book, a post-classical tendency of choosing between any immediate ancestors as sources of country identity has been emerging.

The southern term agu ngalagun has an equivalent in Wik-Ngathan in aak tha' mayng (respect form: aak thaanth math), literally 'country mouth together'. The Wik-Mungkan equivalent is aak thaa' karrp (same translation). This refers to company land, land held in common between two or more identifiable land-associated groups. Dative pronouns, commonly used for possessive constructions, are frequent in the use of such expressions, e.g. aak ngampunt mayng ('our [plural inclusive] joint land', Wik-Ngathan). Places held in common between two or more clans are in this company category in its narrowest or strictest sense, but conjoint interests in land extend outwards from this most local sense to the arena of the cluster of a number of adjacent estates and even to the wider riverine groupings of many estates (see next section). 
There was in the past, and to a far lesser extent in recent decades, a correlation between the geographic closeness of clan estates and the genealogical closeness of their traditional owners. Close relations (Wik-Ngathan un'eth) are classically associated with a particular local district, known as aak uu'eth, 'home country' (Sutton 1995a:114), more specifically 'area of one's blood relations and close family'. This may be larger than a single clan estate but is smaller than a large region such as the Archer-Kendall area, although it is the sort of term that would have variable scope of reference depending on social context.

\section{Small estate clusters}

In a number of cases, two clan estates are very closely linked and on occasion spoken of, and perhaps at times strongly conceived of, as being 'one'. Estates 14 and 27, for example, are contiguous and lie on tributaries of the same river system, the upper Kirke River. At times in the past they have been presented to ethnographers as two distinct but closely linked estates, each held by minimally distinct clans - that is, the clans in each case have all totems in common except one, and this one difference is reflected in the major surnames now associated with each clan (Pootchemunka and Ngakyunkwokka; see Appendix 1: Clans 14 and 35; Appendix 2: Estates 14 and 27). By the 1990s, however, the two estates had essentially merged to become one.

The two clans retained their distinct identities as sets of surnamed descent groups and indeed experienced a marriage between two of their respective members. In any one generation their members are not 'brothers and sisters' but 'cousins', so marriage between their members is certainly not prohibited by traditional incest prohibitions on marriages between (real or) classificatory siblings. So, in an exceptional case having 'one estate' is not of itself a bar to intermarriage. Nor is the possession of some or even many of the same totems a bar to marriage. The key bar to marriage or the forming of a recognised liaison among Wik people, aside from local political factors, is being in a kinship relationship deemed unacceptable, either by closeness of blood, or by reason of being in the wrong category (such as classificatory 'father/daughter', 'sister/brother' or 'mother-in-law/ son-in-law'). 
In another case it is clear from a comparison of McConnel's 1929 data (McConnel 1930b) and our own that two closely linked estates have been, at least for some long time, merged into one in the area of Running Creek, which flows west to the Archer River, and the adjacent head of a tributary running south-west into the Kendall River. That is, in 1929 McConnel's 'local groups' IX(a) and IX(b) had estates that together are now identified as Estate $49\left(K u^{\prime}-a w\right)$, belonging to Clan 39 (Koowartas). In 1929 the members of McConnel's group IX(a), antecedents of the present Koowartas and with an estate on Running Creek, numbered eight to 10 people, while group IX(b) (whose estate was on a Kendall tributary) contained only one surviving member, who was female. The extinction of the patriline for the latter group must have occurred not long afterwards, as by the 1990s any distinction between the two estates appeared to have lapsed. This cannot be taken to be the end of the story, though. The fact that the Running Creek drainage is into the Archer River system, while that of old estate IX(b) is into the Kendall system, remains obvious and may well form the basis of the re-emergence of two estates here in the future, especially given current population increases among Wik people.

In a different case, that of Estates 3 and 4 (Small Lake and Big Lake respectively), the very close linkages between the two estates, which are contiguous and on the same drainage system flowing south to the Kirke River, have allowed them to almost become one. These two areas are known in local languages as Uthuk Eelen ('Small Lake') and Uthuk Aweyn ('Big Lake'), or Weenem Eelen and Weenem Aweyn (Wik-Ngathan), or Uthuk Mayn and Uthuk Pi'an, or Weenem Mayn and Weenem Pian (Wik-Mungkan), respectively. These two lake names are references to stellar constellations (uthuk, 'Milky Way', weenem, 'Southern Cross'), possibly also to lawyer cane (weenem). They are qualified by the adjectives eelen $(\mathrm{Nn})=$ mayn $(\mathrm{Mn})$ 'small', and aweyn $(\mathrm{Nn})=$ pian $(\mathrm{Mn})$ 'big'. Their English names, unpoetic as they are, are used here as they are more widely known.

In the pre-World War II period, Clan 3 and Clan 4 had been of common language, Wik-Elken, and shared at least their major totem (Magpie Goose), but their members had intermarried. By the mid1970s Estate 3 (Small Lake) had long been without clear successors after its former owning clan (Clan 3) had become extinct. At that time a series of succession negotiations was entered into between parties with interests in the estate. A few people of Clan 6 had had a father's mother from Clan 3 and they sought succession on this basis. One man from 
the adjacent Estate 28 (Clan 31) claimed long association with the area from babyhood. Members of Clan 4, with the abutting Estate 4 and a past history of close intermarriage with erstwhile members of Clan 3, maintained an interest also.

The arguments of the person who claimed long if intermittent physical presence on the estate were widely dismissed as insufficient. The descentbased claims were treated with considerable respect. By the early 1990s the succession had been effectively resolved in favour of members of Clan 4 (two branches: Ampeybegans and Bowendas, the latter being in the first rank in relation to Estate 3 and therefore now given a distinct Clan number, 59). Whether Bowendas could maintain central roles in the affairs of both estates ( 3 and 4) for very long was not clear. Members of Clan 4 could claim an exceptional combination of ancestral connections, immediate estate proximity, same dialect as that of Clan 3, a shared principal totem Minh Kalpay (Magpie Goose), and a history of presence on the estate under negotiation, on top of which they had a vigorous and prominent spokesman, Denny Bowenda (1932-2008). It is my view, however, that the original close structural linkage between the two estates also mitigated against their becoming further 'separated' through a succession involving people from south of the Kirke (from Estate 6) who were making an attempted succession to Estate 3 on the basis of ancestry.

In the area of the lower Embley River there are estates held by a set of clans whose totems are almost all the same (Clan 67/Estate 46, Clan 68/ Estate 47, Clan 70/Estate 39, Clan 80/Estate 146, Clan 84/Estate 149). Two of these, however, are of the Alngith language (Clans 67, 80), two are of Linngithigh language (Clans 68, 84) and one is of Mamangathi language (Clan 70). There are contexts in which estates 46 (lower Embley south side) and 146 (Weipa Peninsula) are regarded as 'one', because of three main factors: the estates are contiguous, the relevant clans share most or all totems, and they also share a common language affiliation. It is clear, however, that at the most localised level a distinction between the two clans and estates was recognised by senior members of both. For most younger people, however, such finer points are today of less importance as they lean more towards an areal approach, still identifying with focal ancestral sites ('main places') but also with an area composed of several classical estates. 
Where a person identifies with a broad Wik sub-area (e.g. 'Bottom Kendall', i.e. the lower Kendall River area), but is unable to be precise about clan estate boundaries, for example, it remains true that their identification with the broader area is historically rooted in their origins as a descendant of a clan that holds a definable estate within it. Such people may refer to older or more knowledgeable individuals if they need to obtain more precise territorial information about themselves. In some cases, the location of estate boundaries is no longer an issue: several clans may have become extinct, leaving a number of estates in an area without proximate title holders ${ }^{17}$ for the time being, and conjoint succession to such estates may be occurring.

In conjoint succession, clans holding neighbouring estates collectively act as custodians of estates whose clans have become extinct. This is true for the Wik-Way area, although in that case there is a distinction (not a very hard and fast one) between the surviving northern and southern Wik-Way, the southern Wik-Way having particular responsibility for the area south of about Beagle Camp. This particular form of 'clustering' is a response to rapid depopulation, which early in the twentieth century seems to have affected the Wik-Way area more than other parts of the Wik Region.

Roth (1905) suggested this depopulation north of the Archer was caused by aggression from the east and south by other Aboriginal people. There is no other evidence in support of this. The population density between the Archer and just south of the Embley was much lower than at Albatross Bay or south of the Archer, to start with, as the zone lacks substantial wetlands and has no rivers. Infertility and disease appear to have been the main causes of depopulation among the Wik-Way, judging from the death records and genealogical data available. ${ }^{18}$

In the area of the Thuuk River and middle lower Holroyd (in their local usages) there are two estates, numbers 123 (near the coast) and 130 (inland). A single Kug-Uthu or 'Dead Body Language' clan group is associated with both, although Estate 123 is particularly associated with two clan segments (A: Ngallametta/Ngallapoorgum/Ngakapoorgum, B: Wunchum) and Estate 130 with a third (C: Mimpanja/Yantumba).

17 See Sutton (1996) for the distinction between proximate and underlying customary Aboriginal titles.

18 In Sutton (2017) I have tabulated the Aurukun records on age at death and cause of death for those people known to the Mission, or known to the Aurukun Shire that succeeded it in 1978. 
In spite of their relative unity, segments A and B have the coastal language Kug-Uwanh, while segment $\mathrm{C}$ has the inland language Wik-Iiyanh. ${ }^{19}$ Homogeneity of language is clearly not a pre-requisite for co-membership of such a group, just as in the lower Embley case examined above. In order to distinguish such clusters of clans and estates, they might be described as 'macro-clans' and 'macro-estates'.

Ursula McConnel thought that such cases of close linkage or possible merging of estates and their clans were the result of recent depopulation in the 1920s. She said:

Owing to the disintegrated state of the clans and their depleted numbers it is sometimes difficult to ascertain where one clan ends and another begins. In cases of uncertainty I have grouped as sections of one clan, totemic groups which may form separate clans (McConnel 1930a:81fn.).

While the frequency of occurrence of such cases might have been accelerated by the loss of population in the region in the early part of the twentieth century, the mechanisms involved seem too consistent and widespread to be described as new developments as such. They seem to rest on classical structural principles.

There are several other kinds of small localised clustering of Wik clan estates. Those dealt with below are 'nickname' groupings, spirit-image centre groupings, cremation countrymen groupings, localised totemic cult groups, and outstation groupings.

Clans with adjacent estates often share what is locally referred to in English as a 'nickname' based on a local environmental typifier or a major placename (see Sutton 1978:126-28). Thus Kuuchenm, for example, is the nickname for several clans with estates characterised by the lancewood tree (yuk kuuchen, Thryptomene oligandra, Sutton 1995a:30) that grows on the sandridges in the lower Kirke River area. (For a listing and map of several such clusters in the area Love River to Kendall River, see Sutton 1978:127, Map 9. $)^{20}$

Clans who send the spirit-images (koetheth maayn) of their recent dead to a common spirit image-centre also make up small clusters of groups with adjacent estates. Some of these spirit-sending centres (aak pam-kaawkeyn

19 John von Sturmer, pers. comm., 1997. See Appendix 1: Clan list.

20 Where recorded, these nicknames are provided for each clan in Appendix 1. 
in Wik-Ngathan, aak kaa'-kuchan in Wik-Mungkan) are used uniquely for the deceased of a single clan, while others may be common to several clans whose estates are clustered together in the same area. For two such sets of estates see Sutton (1978:Map 12). Human spirit-images are normally sent to their homeland areas at night and shortly after the death. The practice was widespread among Wik peoples until recently. It was a form of continuity in the maintenance of connection with country, which an outsider might describe as 'cultural' or 'spiritual' but which for those engaged in the practice involves the sending of an aspect of a person's actual substance to their traditional country.

Sets of clans whose members were cremated in common cremation grounds, prior to the introduction of burial as a result of mission influence, constitute sets of 'countrymen' (in Wik-Ngathan, aak-koenth) at a certain localised level. In the 1970s older people could list the clans whose members were cremated at such single points. Such clusters were probably in general made up of just a few clans whose estates were adjacent (see Sutton 1978:128, Map 12).

There are also small clusters of estates whose primary holders share a localised totemic cult affiliation, such as Shark in the lower Kirke River area (Estates 4, 5, 6, 7, 8), and Dog in the lower Knox River area (Estates $15,16,18,20)$. For further examples of these particular types of clusters see Sutton (1978:140).

The clans holding the estates closest to, and including, a particular outstation also form clusters for whom the name of the outstation may function as a common badge of identity. In some cases, tee-shirts carrying the name of the outstation may be purchased and worn by members of clans from such clusters, especially at special events such as mortuary ceremonies. The name of an outstation has become a legitimate, if only middlingly precise, form in which people may answer questions about where their traditional country lies. (For examples of four outstation clan estate clusters studied in the 1970s see Sutton 1978:Map 13.)

\section{Riverine identity groups}

Clans with estates on the same riverine drainage system are typically significant allies who for a long time past have closely intermarried and who identify with each other, both in times of conflict and at other 
times, by reference to their common river of origin. Before the advent of English, the riverine group names appear in the main to have been based on an extension of the scope of the name of a principal site close to the mouth of the river, except where the relevant grouping was based on just the upper reaches of a large river system. The Love River people were formerly known as the people from Thoekel (known in another dialect as Thukali, the 'Tokalie River' of old maps), the name of a base camp site near the river's mouth. The 'Cape Keerweer' (lower Kirke River) people were formerly known as the people from Yu'engk (the missionaries' 'Yonka River'), a site near the Kirke mouth. The 'Knox River' people were formerly known as the people from Eeremangk (the missionaries' 'Errimangk'), a site at the mouth of that river. And so on. Rivers as wholes were not named. Creeks were named 'X-arm' where X was a site name, as in Punth Iincheng 'Iincheng Creek'.

Between the Archer and Embley rivers, depopulation earlier in the twentieth century may have reduced the effectiveness or relevance of identity groupings based on the lower Archer, Ward and Watson rivers, but it is also notable that no major river system enters the sea between the Archer and the Embley, so the geography does not lend itself easily to riverine groupings in the way that the area south of Archer River does.

The area from the lower Archer to the Embley is often referred to collectively as 'Wik-Way', but there is still a distinction made, at times, between the lower Archer/Ward River/Norman River area and the zone between there and the Embley, the latter being the northern Wik-Way area. The Watson River area is not usually identified as Wik-Way and is often conjoined with the adjacent Tompaten Creek area. The latter is locally known as Small Archer and the relevant riverine identity is also described as 'Small Archer' (see Appendix 2).

By the 1970s, the main and active riverine group terms were:

- 'Archer River' (subdivided into 'Small Archer' (Tompaten Creek) and 'Main Archer', the latter again subdivided into 'Top Archer', 'Bottom Archer' and 'Archer Bend')

- 'Love River' (subdivided into 'Bottom Love' and 'Top Love')

- on the Kirke River system: 'Cape Keerweer' (lower Kirke River system), 'Kencherrang' (middle Kirke River, an outstation name), 'Oony-aw' (upper northern Kirke tributary, a site and estate name), 'Ti Tree' (upper eastern Kirke River tributaries) 
- 'Knox River' (the Knox Creek of official maps)

- 'Kendall River' (subdivided into 'Top Kendall', 'Bottom Kendall' and 'South Kendall', the latter being the 'Holroyd River' of official maps)

- 'Thuuk (Snake) River' (the Hersey Creek of official maps)

- 'Christmas Creek' (the Balurga Creek of official maps)

- 'Holroyd River' (the Christmas Creek of official maps, subdivided into 'Top Holroyd' and 'Bottom Holroyd').

Note also that the lower Edward River is in local Kugu Ngancharra usage referred to as 'Breakfast Creek'.

Relationship patterns after the mid-1970s show a gradual trend away from tight-knit marriage clusters or connubia within these riverine groups (Martin 1993:Chapter 2, cf. Sutton 1978:106-17), but as forms of identity based on country of origin the broadly inclusive riverine groupings, and Wik-Way as a different kind of sub-regional designation, continued to have great salience for Wik people.

\section{Regional ceremonial groups}

Large sets of clans with estates in a particular sub-region, typically one larger than any of the cluster areas described above, make up the five ceremonial groupings Shivirri, Apelech, Winchanam, Puch and Wanam, locally referred to at Aurukun as 'the five clan groups' (Map A1.1).

The Shivirri (also known as Shivri, Chivirri, Saarra) ceremonial group is more or less co-extensive with the category of Wik-Way, and relates to the sub-region from the Archer to the Embley River.

Winchanam, being the northern inland Wik ceremonial group, includes the majority of the 'topside' people within the Wik universe. The relevant sub-region is basically the middle and upper Archer system and Small Archer (Tompaten Creek), south via the heads of the major watercourses to the upper Kendall-Holroyd area. The late John Koowarta belonged to this ritual group, and its name has thus entered legal history. ${ }^{21}$ Although now principally identified with a particular inland ceremonial content

21 Koowarta v Bjelke-Petersen (1982) 153 CLR 168. 
and style (dance, myth, song, paint), Winchanam was also the name of the second stage of male initiation across the whole Wik Region south of Archer River, a ceremony that was last held in 1970.

The 'bottomside' (coastal) Wik people, i.e. people whose ancestral clan estates are on and near the coast or coastal floodplains south of the Archer River, belong to either Apelech, Puch or Wanam ceremonial groups. Apelech group members have estates on the upper and lower Love, lower and middle Kirke, and lower Knox rivers. South of there, Puch (also known as Key-elp) estates are on the lower Kendall and Thuuk rivers. Further south again, Wanam estates are on the Holroyd River and Christmas Creek (as named in in local usage). Clearly, the entry point to membership of these five ritual groups is via one's clan of birth.

These ritual groups have unambiguous core memberships, but some of their core members' estates border on those of neighbours whose inclusion in the same ceremonial group is less definite or central, or who have dual identification with adjoining ceremonial groups. For example, the lower Knox River estates $(15,18,19,20)$ are Apelech, like those to their north as far as Love River. The middle Knox River people of Estate 16 'come in with' Apelech and 'give them a hand', and are described as 'mixed [with] Apelech' but are not widely regarded as Apelech pure and simple. Their own immediate inland neighbours, on the head of Knox River, are Winchanam (see Appendix 2: Estate 17) like most of the other northern inland Wik groups.

Thus, between the coast proper and inland proper there are sometimes estates and estate-holders, who are intermediate between the two in terms of certain aspects of cultural identity and alliance patterns.

These ceremonial group identities remain of importance for Wik people. Performances of their distinctive dramas are a regular part of house-opening ceremonies for deceased Wik individuals (see the film House-Opening [1980]). The heroic legendary figures of such ceremonial forms are held to have allocated the estates of each particular subregion to the various totemic clans at the foundation of the world (Sutton 1997b). 


\section{The coast/hinterland distinction}

The broadest and most powerful internal geopolitical distinction among the Wik peoples is the coast/hinterland division, often referred to locally as 'bottomside' and 'topside' people, or the equivalent 'saltwater' and 'freshwater' people. This was so in the past, when the population was far more decentralised, but it remains highly significant in spite of the fact that most Wik people now spend most of each year close to the coast at Aurukun.

This is clearly because the relevant terms refer not to residential arrangements but to the location of the clan estates of the relevant people, regardless of where those people reside. Many of the estates of Wik people are far distant from settlements such as Napranum, Aurukun or Pormpuraaw. Not all are near outstations. Thus the distinction is ultimately one between people as land-holders, made on the coast/hinterland axis, not one based on population distributions. One is an inlander or a coastal person, a freshwater or saltwater person, for life.

At Aurukun there has long been a decreasing correlation between where people are housed in the village and the orientation of their estates of origin, but many inlanders still live at the eastern (inland) end of Aurukun and many coastal people still live at the western end-the 'topside' people of the village are concentrated at the upper or inland end, and the 'bottomside' are concentrated at the lower or Gulf end. This reflects the universal tendency of classical Aboriginal groups to reside on the side of a residential site that reflects their territorial origins.

\section{Communities}

This term is used in three main ways in writings on Aboriginal people. One refers to what Barry Smith (1989) has called the 'geographic community', basically the population of Aboriginal people at a settlement such as Aurukun, Napranum or Pormpuraaw, regardless of how socially integrated such a collectivity may or may not be. Another sense of 'community' refers to an Aboriginal social field within the wider context in which it is embedded, such as the Aboriginal community of Cairns, or the Aboriginal community of Australia. 
The third sense is one confined to anthropological writings such as those of Meggitt (1962) and Hiatt (1965). In these cases, one from the fringe Western Desert (Meggitt) and one from north-central Arnhem Land (Hiatt), clusters of local land-holding groups were named and these authors also implied that these named groups were land-occupying groups as well. From a detailed examination of their data (Sutton 2003:98-107), I have concluded that if these 'community' names were used in this latter sense, it was by extension or in some other way distinguishable from their primary function as titles for clusters of tenurial units.

Such a dual function also seems to be characteristic of Wik names that refer primarily to localised clusters of estates and their relevant clans. Thus riverine terms such as 'Kendall River mob' might on occasion refer not only to people whose ancestral country lies on the Kendall drainage system, but by extension to such people together with their spouses and others living with them at a certain time.

\section{Tribes and language groups}

A common language affiliation may be shared by clans that have contiguous estates, but it may also be shared by clans with non-contiguous estates. In the latter case, these clans may belong to different sub-regional political groupings such as different riverine alliances and regional ritual groups. The distribution of any one language can be mosaic-like, cropping up here and there across the landscape, separated by estates belonging to other languages. ${ }^{22}$ Earlier ethnographers did not know enough about the details of land relationships and language affiliation to know this, and produced a 'one language per area' model on maps (Maps 3.1-3.7). ${ }^{23}$ Specific Wik languages are not typically coterminous with the salient geo-political classical groupings of the region.

22 See Map 2.3 in Sutton (1991:63).

23 Maps 3.1-3.7 are details of those published by McConnel (1957:xviii), Sharp (1939:440), Thomson (1972:vi), Tindale (1940, 1974 [including maps]), Walsh (1981-83), and Dixon (2002:xxviii). These are the principal linguistic maps of the study area based on independent research other than those presented in Maps A2.1-2.13. 


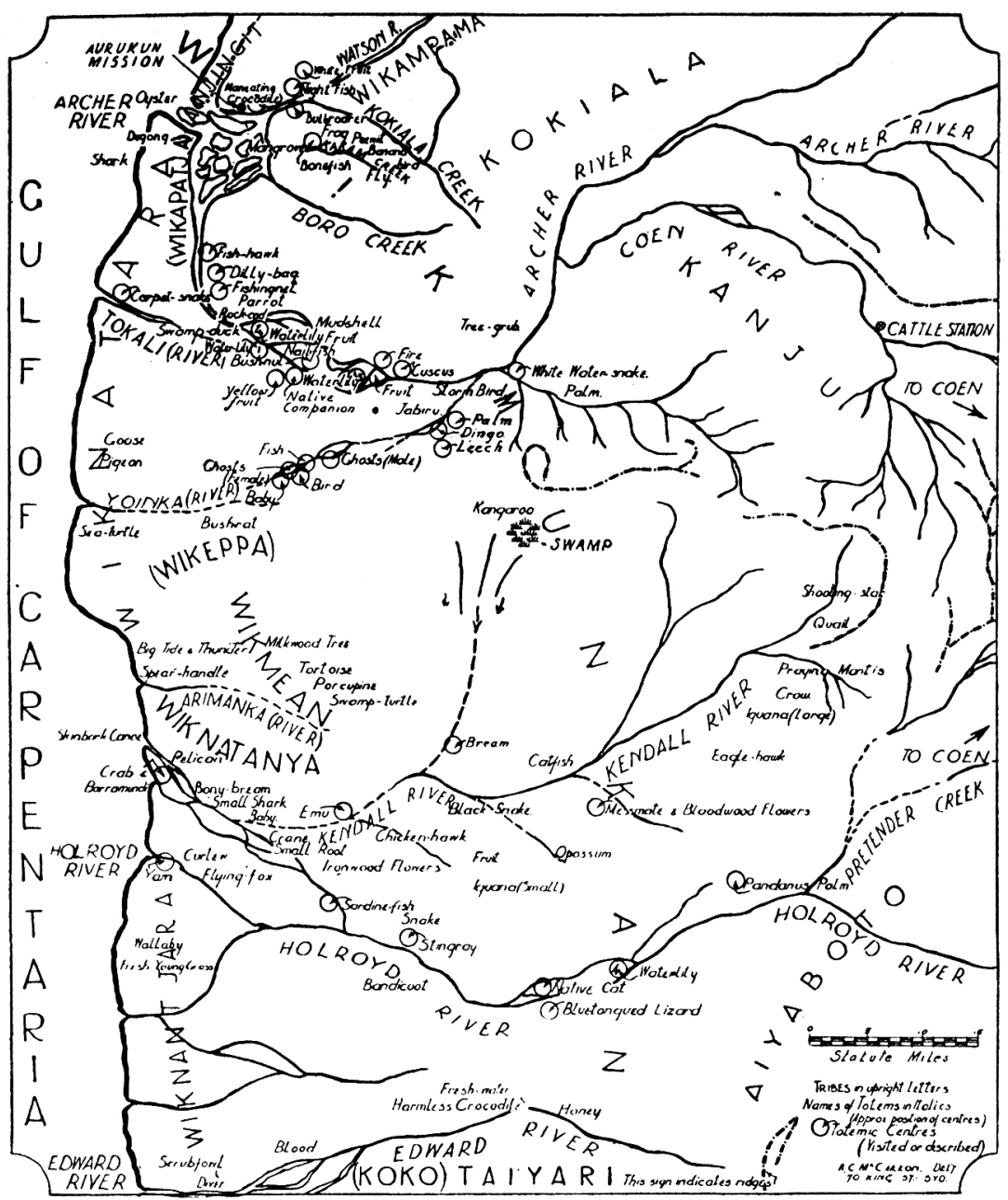

Map 3.1: WCYP language countries (McConnel)

Source: McConnel (1930a) 


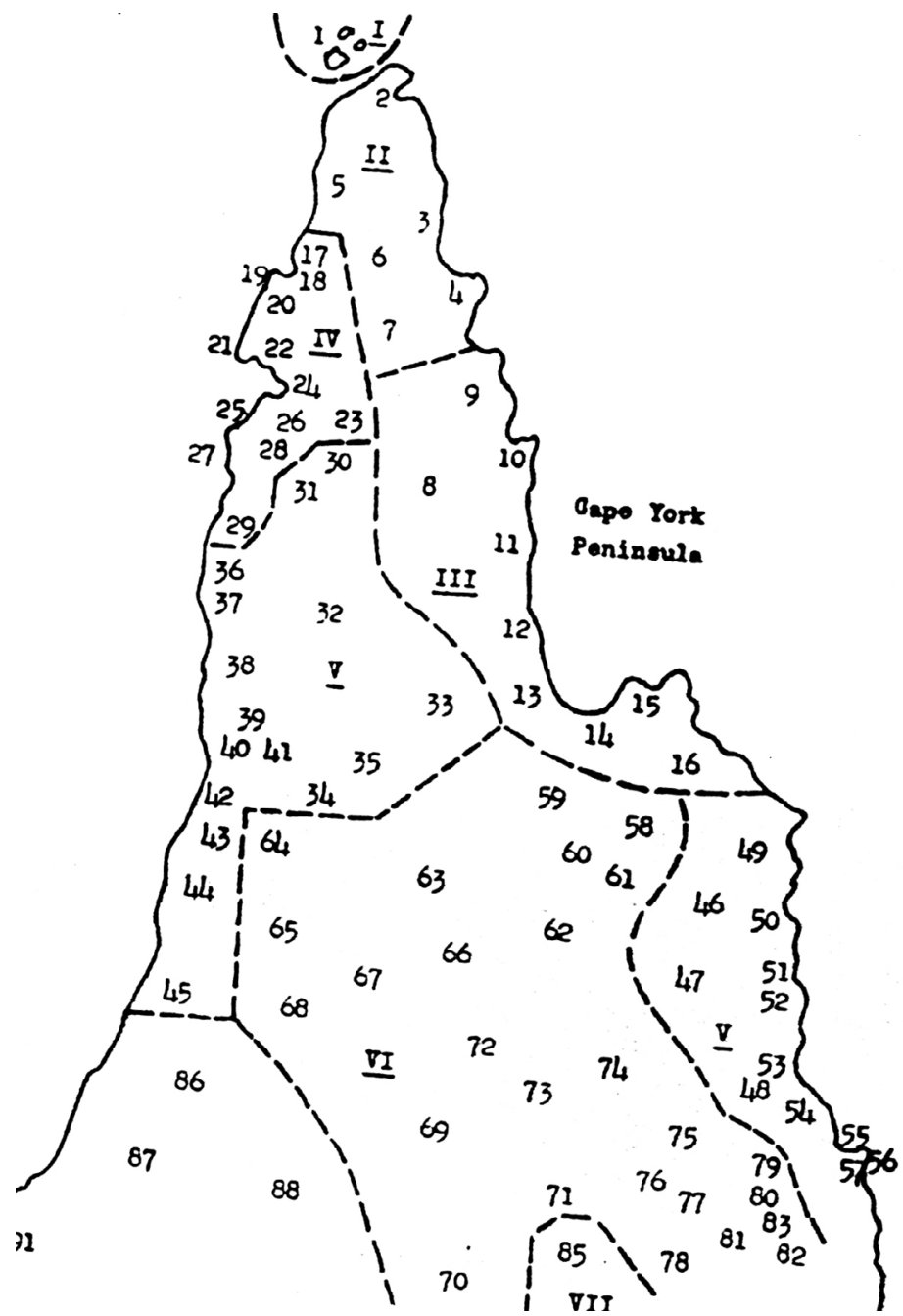

\section{Map 3.2: WCYP language countries (Sharp)}

IV 24 Tjongandji type: 17 Ngathokadi; 18 Tepethiki; 19 Tjongandji; 20 Yop'ngadi;

or Ngerikadi; 21 Wimarango; 22 Ngwatangeti; 23 'Kauwala'; 24 Lenngeti; 25 Mamanget; 26 Latangeti; 27 Anda'angeti; 28 Aditinngeti; 29 Wik Alkina or Wik Natera.

Extinct tribe: Wik Tinda and perhaps others.

V Yir Yoront type (western sector only):

30 Kok Mbewam; 31 Kok lala; 32 Wik Munkan and Wik lanyi; 33 Aiabado; 34 Aiakampana; 35 Aiabakan; 36 Wik Me'ana; 37 Wik Natanya; 38 Wik Ngantjera; 39 Ngantja; 40 Ngentjin; 41 Taior; 42 Yir Yoront; 43 Yir Mel; 44 Koko Pera; 45 Koko Papung and Koko Paperum.

Source: Sharp (1939)

24 Sharp's Roman numerals here refer to types of totemic systems. 


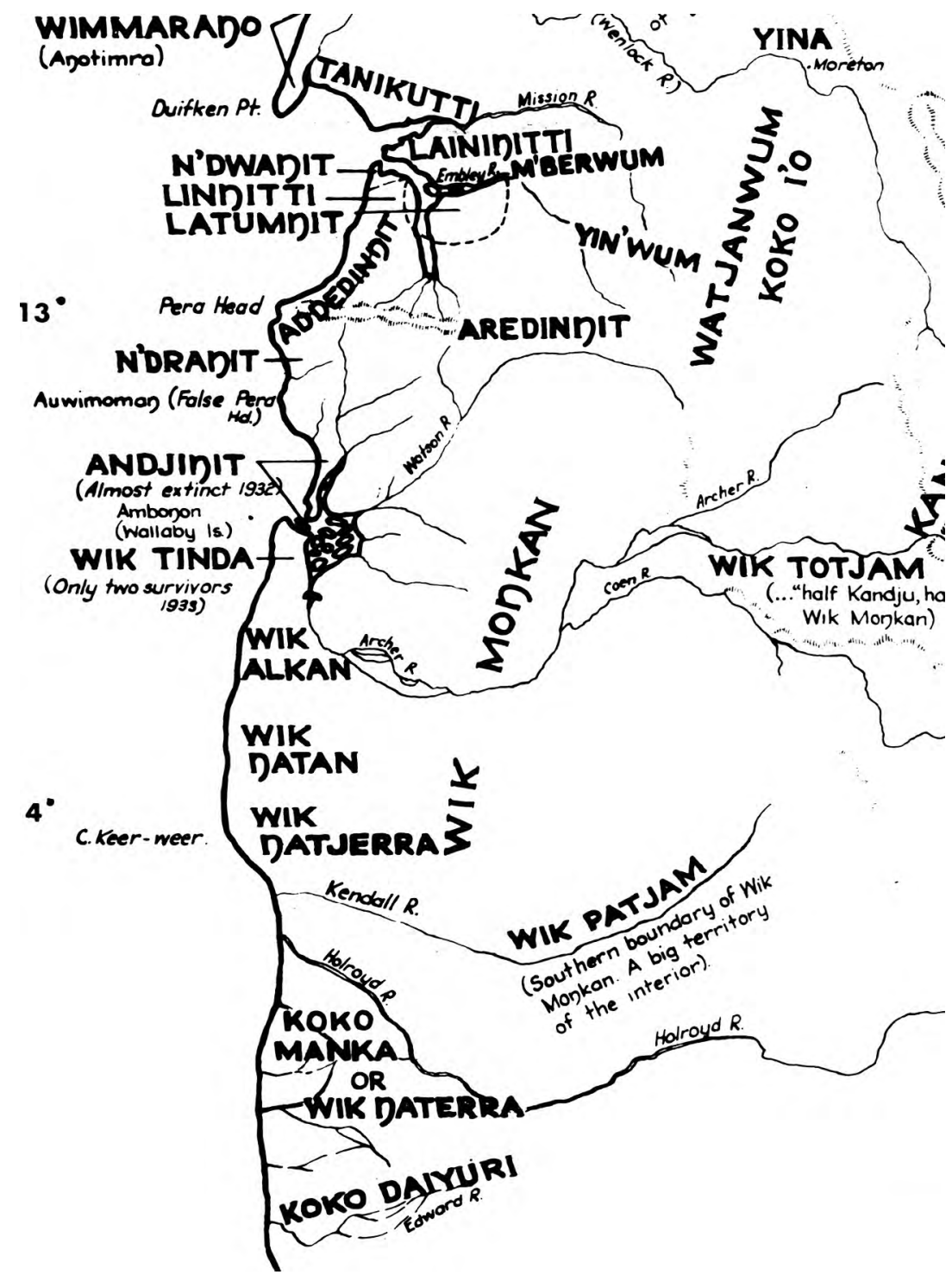

Map 3.3: WCYP language countries (Thomson)

Source: Thomson (1972) 


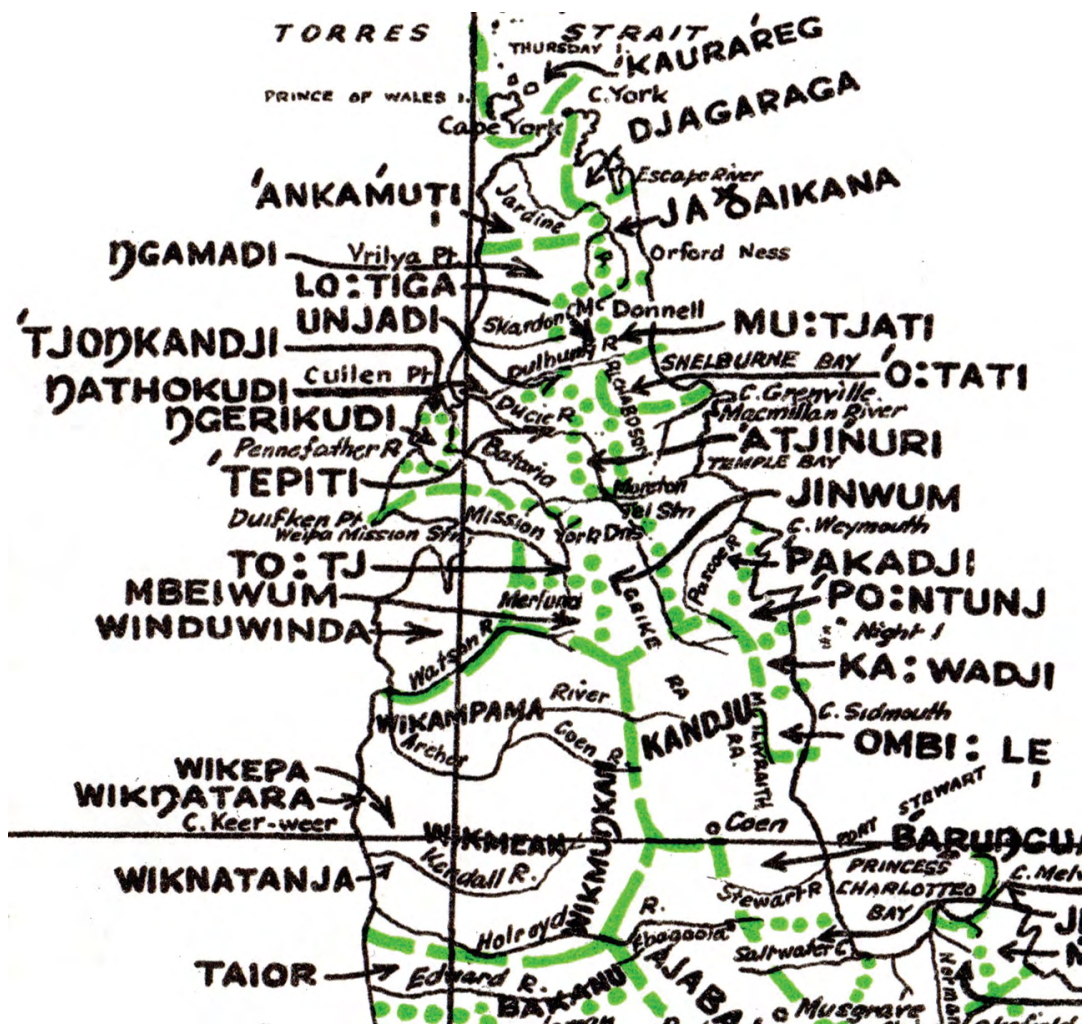

Map 3.4: WCYP language countries (Tindale 1940)

Source: Tindale (1940) 


\section{WIK-Small tribes}

1 'WIK'APATJA

2 'WIKATINDÁ

3 'WIKEPA

4 'WIK'KALKAN

5 'WIK'NATANJA

6 'WIK'NANTJARA

7 'WIKIANJI

8 'MIMUDKUM

9 'WIKMEAN

10 'WIKAMPAMA

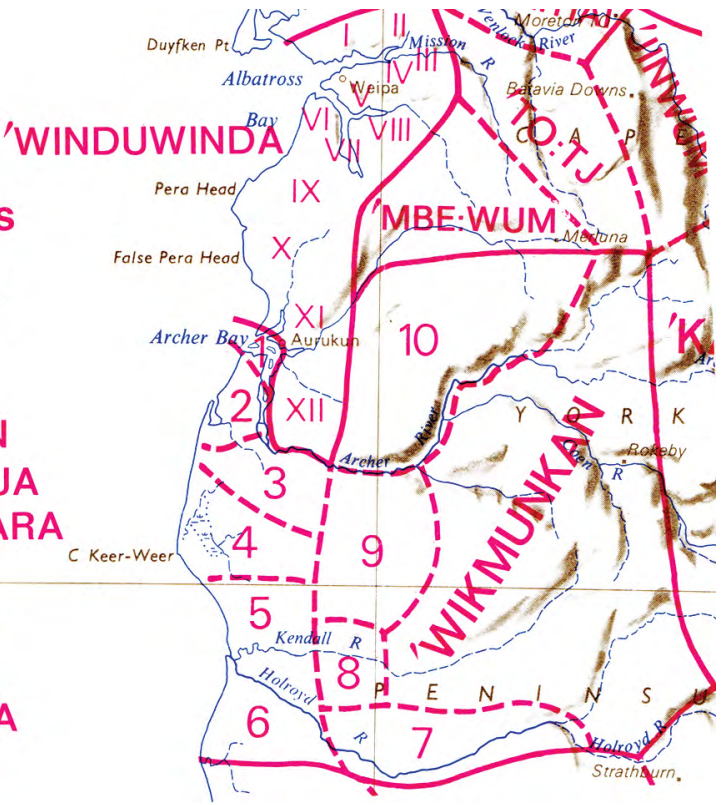

\section{Map 3.5: WCYP language countries (Tindale 1974)}

I Tanikuit [Thanikwith], (Tannikutti, Dainiguid, Tannagootee)

II Ndruangit [Ndrwa'ngith]

III Ndwangit [Ndwa'ngith], (Ndwongit)

IV Ngawangati (Ngawateingeti, Ungauwangati)

$\checkmark$ Alingit (Lengiti, Lenngiti, Alngid, Limretti [?typographical error]) ${ }^{25}$

VI Mamangit [Mamangith], (Mamangiti, Mamngaid)

VII Latamngit (Lätamngit)

VIII Nggot (Gott)

IX Aretinget [Arrithinngith]

$X$ Ndraangit

XI Leningiti

XII Andjingit

Source: Tindale (1974) 


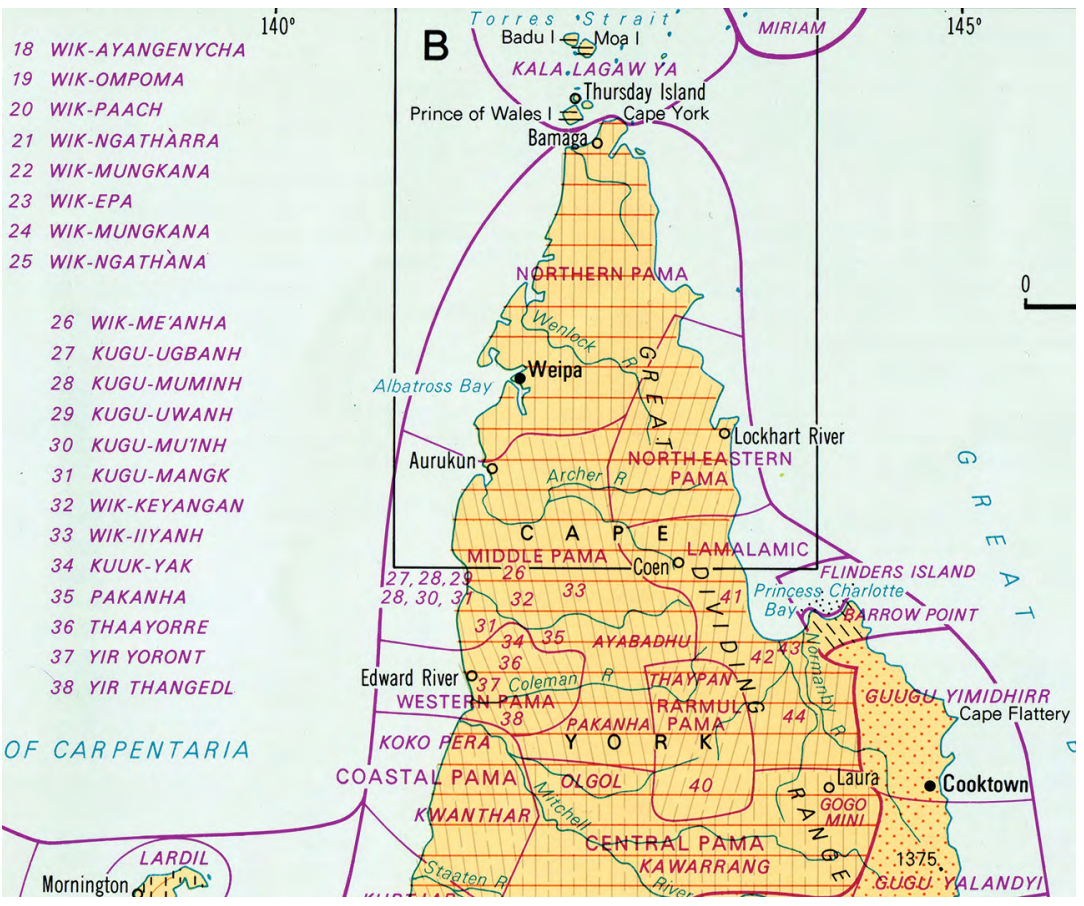

\section{Map 3.6: WCYP language countries (Walsh)}

Source: Walsh (1981-83)

In Wik tradition, several clans may have a common language, with a single shared name such as Andjingith, Mbiywom, Wik-Ngathan, Wik-Me'enh, Wik-Mungkan, Kugu Uwanh or Kugu Muminh. The languages may have different names depending on the variety being used. Hence, self-named Andjingith is known as Wik-Ayangench in Wik-Ngathan, self-named Mbiywom is known as Wik-Ompom in Wik-Mungkan, self-named Kugu Muminh is known as Wik-Muminh in Wik-Mungkan, and so on. ${ }^{26}$ These names are generally based on distinctive items of vocabulary. For example, muminh means 'go, walk', and mungkan means 'eat', and ngathan is a rarely encountered oblique first person pronoun 'mine'.

26 For a catalogue of such alternate language names see Chapter 5. 


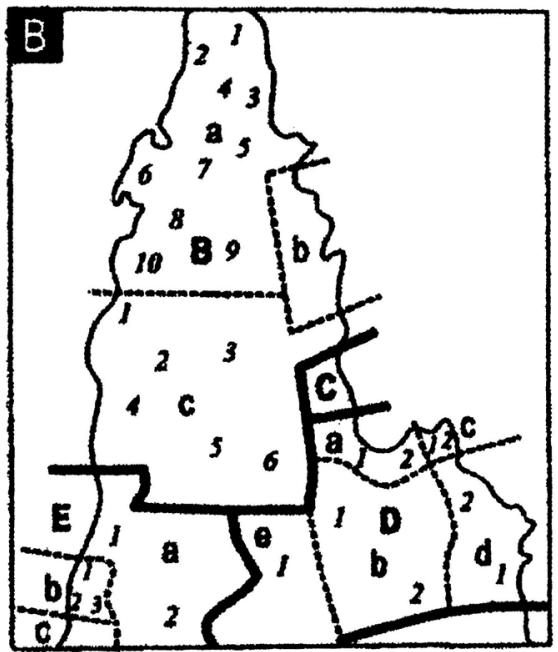

\section{Map 3.7: WCYP language countries (Dixon)}

Ba Northern Paman subgroup

Ba1 Gudang (other dialect: Djagaraga)

Ba2 Uradhi (other dialects Angkamuthi, Yadheykenu, Atampaya)

Ba3 Wuthati

Ba4 Luthigh (other dialect Mpalitjanh)

Ba5 Yinwum (probable other dialect Njuwadhai)

Ba6 Anguthimri (other dialects Nggerikudi or Yupungati, Tjungundji, Mpoakwithi, Awngthim (with subdialects Mamngayt, Ntrwa'ngayth, Thyanngayth), Ntra'ngith, Alngith, Linngithigh)

Ba7 Ngkoth (other dialects Tootj ${ }^{27}$ (or Kauwala), Ngaawangati or Ungauwangati)

Ba8 Aritinngithigh (or Aritinngayth) (other dialect Latamngit)

Ba9 Mbiywom

Ba10 Andjingith

\section{Bb Umpila (other dialects Kuuku Yani, Uutaalnganu, Kuuku Ya'u, Kaantju)}

\section{Bc Wik subgroup ${ }^{28}$}

Bc1 Wik-Ngathan (= Wik linjtjenj) (other dialect Wik-Ngatharr (= Wik-Alken = Wik-Elken)

Bc2 Wik-Me'nh (other dialects Wik-Ep (= Wik-lit), Wik-Keyenganh)

Bc3 Wik-Mungknh (Wik-Munkan) (other dialects Wik-liyanh (= Wik-liyenj = Wik-liyanji = Mungkanhu)

Bc4 Kugu Muminh (Wik-Muminh) (or Kugu/Wik-Nganhcara) (other dialects Wik/Kugu

+ Mu'inh, Uwanh, Ugbanh, Yi'anh, Mangk, lyanh)

Bc5 Bakanha (or Ayabakan(u))

Bc6 Ayabadhu

Source: Dixon (2002)

27 I think this is a typo for Trotj: PS.

28 Dixon also published a specific map called 'Languages of the Wik subgroup, Bc' (Dixon 2002:387). 
Wik clans, according to local traditions, acquired their languages during the founding legendary period when heroic figures implanted local dialects along with sacred sites, culture, and customary law in the landscape (Sutton 1997b). Languages are an important form of symbolic property, and one's own 'real language' is thus something normatively acquired by patrilineal descent, in the classical system. Merely being fluent in such a language does not confer proprietary rights in it, nor does the inability to speak one's clan's language deny one the right to claim it as one's own.

While on occasion the fact of sharing the same language may be adduced as evidence of some form of unity of identity with someone else, this is far less common here than in most parts of Aboriginal Australia. In short, the Wik show little commitment to the notion of the 'language group' as a geopolitical unit of much salience, and do not normally use these language names as names of land-based identities with proprietorial significance, although they always have sub-regional connotations. It is true that cover terms such as Wik-Way (an exonym 'Language-Bad' referring to a variety of languages between the Archer and Embley rivers) and WikNgencherr (an exonym referring to the self-named Kugu Ngancharra, the southern Wik peoples whose language names begin with Kugu), do have geopolitical substance in the region, and refer to sets of languages, even if these sets are not uniquely and highly bounded. Non-Wik people, such as Thaayorre people at Pormpuraaw, have long recognised the people from between the Archer and Edward rivers as having a certain unity, one that they mark by calling them 'Mungkan' or 'Mungkan-side' people, as is the case at Pormpuraaw (Taylor 1984) and at Coen and Port Stewart (Sutton et al. 1993). This again is an exonym not usually used by Wik people themselves. It is a case where a lingua franca dialect name has become adopted as the outsiders' collective term for the polyglot nation hosting that lingua franca. Exonyms typically simplify things.

At a finer-grained level, however, there is indeed a 'language group' model of land tenure among Wik people but this arises from their classical view that each clan has (or had) a distinctive dialect, one associated with their estate and their clan or clan segment's principal totem (Sutton 1991; von Sturmer 1978:325). ${ }^{29}$ The phenomenon was widespread in classical

29 For further elaboration of Wik traditional dialectology see Sutton (1991:55-59). 
Australia. The Wik Regional clan dialects are sociologically largely the same as the 'patrilects' described by David Nash (1990) for the northcentral Northern Territory.

Thus, for example, northern Yunkaportas (Clan 12) may be referred to as Wik Korr', '[Those with] Brolga Language', and the largest segment of the Wolmbys (Clan 6) as Wik Chiiynchiiyn, or Nguungk Chiiynchiiyn '[Those with] Bushrat Language'. ${ }^{30}$ However, clans that share a principal totem, and thus are said to have 'the same Story' and thus the same totemic dialect name, may also recognise dialectal or even deep linguistic differences between their speech varieties. For example, Clan 123 has Kugu Uthu 'Dead Body' as principal totem, as also does Clan 130, but the dialect of Clan 123 is Kugu Uwanh while that of Clan 130 is Wik-liyanh.

\section{Society, nation}

The anthropological use of the term 'society' would not normally apply to the Wik, or to Aurukun, or to any of the smaller groupings I have discussed, but might apply to, say, the Aboriginal people of Cape York Peninsula or indeed of mainland Australia as a connected whole.

The term 'nation' could apply to the Wik peoples as a whole. Elsewhere I have discussed such entities on a continent-wide basis (Sutton 1990, 2003:90-2, 97-8).

In view of what I have suggested above, the model that seemed most appropriate for asserting native title in the Wik case was one of the clans, not separately and severally but collectively, articulating with each other in a complex way to form higher-level groupings of varying scopes, within the broad rubric of the Wik (including the Wik Way ${ }^{31}$ ) nation. The consent determinations in favour of their claim repeatedly referred to the successful applicants as 'the Wik and Wik Way peoples'. ${ }^{32}$

30 Note that wik and nguungk are equivalent in meaning, but the latter is the respect form, and both may be encountered in this context.

31 Wik Way, with no hyphen, in this book refers to legal usage; Wik-Way is my anthropological usage, based on primary word stress on /wik/.

32 Wik Peoples v State of Queensland [2000] FCA 1443; Wik Peoples v State of Queensland [2004] FCA 1306; Wik and Wik Way Native Title Claim Group v Queensland [2009] FCA 789. 
Membership in any of the higher level country-based Wik groupings above the clan level depends critically on one's clan membership in the first instance. Socially recognised descent is the cornerstone of clanship. Riverine group, ritual group and nation memberships flow ultimately from the most local of affiliations to clan and estate. It is these latter ancestral ties that link individual Wik people back to the countries their forebears held and occupied before their residential arrangements were significantly altered in the last century, mainly through centralisation and the new economy.

It is important, in the present context, that the various Wik peoples share a common set of principles governing both tenure and use of land and waters. The system of 'traditional laws and customs' 33 under which individuals hold their rights and interests in country in the Wik Region is not an individual creation, or a clan creation. It is the creature of the Wik nation and the wider society of other Aboriginal nations to which the Wik belong. Wik customary tenure law does not have a hard and fast geographical or social boundary, beyond which all or most aspects of customary tenure law are different. The Wik share much with their neighbours to the south, east and north.

One reason why the Wik native title application was made by the Wik and Wik Way peoples collectively, rather than by separate clans, or separate riverine groups, for example, was not merely for reasons of convenience and economy, but more importantly because it is only at the wider societal level that the self-sustaining nature of the tenure system becomes fully functional. ${ }^{34}$ It is also at this wider level that the relative coherence of the Wik tenure system, as played out in any given location, becomes adequately apparent to the observer. This is made most plain when one considers the nature of succession to estates whose clans' patrilines have died out. There are many examples of kinds of succession in Appendices 1 and 2. Briefly, such cases show that succession to estates whose clans have

33 This is the antique language of Section 223 of the Native Title Act 1993. McConnel (1957:168) used the expressions 'native law', 'tribal law', and 'native laws' in relation to the Wik. In that context she was writing in particular about social control and conflict resolution, but her detailed accounts of land tenure in the region may also be defined as accounts of customary laws regarding proprietorial interests in country.

34 On the general problem of 'slicing the pie'-determining the most appropriate level of inclusiveness at which native title applicant groups should be defined-see Sutton (1995c). 
died out is not an arbitrary matter, or a matter for resolution by brute force. While bases of competing succession arguments may differ, the Wik recognise only certain kinds of arguments as legitimate. ${ }^{35}$

\section{The Wik}

The Wik peoples are a regional Aboriginal cultural group. Like other regional groups of similar type, which are often called 'nations' or 'confederacies', this one consists of a number of subgroups as outlined above. The Wik subgroups share cultural heritage, exercise a mainly common system of custom and law in relation to land, and engage in a set of active interrelationships that mark them as distinctive, although they have until recently had no autogenous collective name for this relative regional unity.

It is common for regional macro-groupings of this type to have no autogenous name for themselves. In eastern Cape York Peninsula, the 'nation' names Lamalama, Yiithuwarra and Kuku-Warra are all derived from the usages of those belonging to areas near to, but outside, those of the nations concerned. Kuku-Warra, interestingly, means 'Language-Bad/ Difficult' as does Wik-Way. In the case of the Lamalama and Yiithuwarra, as in that of the Wik-Way and now the Wik generally, the outsiders' title for them has recently become internalised.

The anthropological literature introduced the terms 'Wik-speaking peoples' 36 (Thomson 1936:374) and 'Wik tribes' (McConnel 1936:455). McConnel in several publications referred to all these 'Wik tribes' on occasion as 'the Wikmunkan' or 'the Wikmunkan and allied tribes', a rather misleading usage. While Wik-Mungkan is the regional lingua franca, only a minority of Wik people identify with the Wik-Mungkan language as being their own ancestral tongue.

Scholars of the 1970s used the term 'the Wik' to refer to the same people (von Sturmer 1978; Sutton 1978; von Sturmer 1980; Martin 1993). The scope of this expression was then limited to those people affiliated with languages of the Wik genetic linguistic group (Wik Subgroup), from

35 See further below under 'Principles of succession'.

36 Strictly speaking, 'Wik-speaking' is not literally what Thomson or others meant by this phrase, as there are people not formally affiliated with or identifying with Wik languages who have nevertheless learned them and speak them well. 'Wik-owning' would have been more appropriate. 
between the Archer and Edward rivers, and thus did not include the WikWay people or their original languages, which belong to the Northern Paman genetic linguistic group (Hale 1964).

The Wik peoples, on a number of cultural and social criteria, may be distinguished, but they are not isolated. No Aboriginal group is an island. Such groups typically have a solidly recognisable core membership and a less well-bounded periphery. The integrity of the gentle gradients between Wik and non-Wik in certain areas, such as that in the area of Rokeby, is not violated by recognising broad unities such as the Wik. On the south the Wik have in the past been far more highly bounded by their meeting with the Thaayorre people, though this is changing through co-residence at Pormpuraaw.

\section{The Wik-Way}

From Albatross Bay to just south of Archer River, along a narrow coastal strip, are the estates of the Wik-Way people (in the modern sense- see next paragraph), whose clans own a set of closely related languages that are radically different from those to the south of them but middlingly related to those of the Mapoon area to the north. Some of these people formed the core of the Weipa Mission ${ }^{37}$ and others formed part of the core of Aurukun Mission as they were established in 1898 and 1904 respectively. On the eastern or inland side of the Wik-Way estates, on the upper Watson River, Kokialah Creek and north to the middle Embley and Myall Creek areas, were the estates of clans whose members are not identified as WikWay in the modern sense, but whose languages were most closely related to those of the Wik-Way grouping, as all were Northern Paman varieties (Hale 1964). In earlier times it seems clear that 'Wik-Way' was a term applied, from a south-of-Archer perspective, to any language to the north, including the inland ones such as Mbiywom and Nggoth.

The modern senses of this term are narrower. The most usual one has the Wik-Way area running from the Aurukun Airstrip (north side) via Ikeleth and the Ward River, north to Embley River, excluding the Watson River system and the Jackin Creek area.

37 Weipa Mission was originally established on the middle Embley River by Moravian missionaries. In 1932-33 it was moved downstream to the coast at Jessica Point and was known as Weipa South. In 1990 it became the Aboriginal Shire of Napranum. 
During the early and middle parts of the twentieth century, many members of clans whose estates lay between the Archer and Embley rivers became based at Aurukun and gradually came under strong cultural influence from the Wik Subgroup peoples, their southern neighbours. Those based at Aurukun shifted their first language of daily use from a Wik-Way-type language to Wik-Mungkan, the Aurukun mission lingua franca. In doing so, they did not abandon their own languages of affiliation, and their descendants continue to identify with those languages, even though they no longer speak them. Wik-Way people have also abandoned a prescriptive marriage rule that was formerly a mark of significant differences between themselves and the Wik Subgroup peoples from the south.

In a number of cases, however, Wik-Way estates clustered about the abutment area of the Northern Paman and Wik linguistic subgroupsthe lower Archer River and Love River areas in particular, and on the upper Kirke River-underwent language shifts from a Northern Paman variety to a Wik Subgroup variety during the late nineteenth and early twentieth centuries. Details of each case are provided in Appendix 2.

Wik-Way people who did not settle at Aurukun became based at Weipa and elsewhere, and there has thus been some cultural divergence within descendants of members of this grouping over several generations. Many of its members may be regarded as culturally 'Wik people', while some others may not, but their country is still regarded, particularly from an Aurukun perspective, as Wik-Way country. There is also some inconsistency in the way 'Wik-Way' identity is ascribed to people at the present time.

Furthermore, the term Wik-Way ('Language-Bad/Difficult'), which is part of local usage especially at Aurukun, is from a Wik Subgroup language, not from a Wik-Way or Northern Paman type of language. ${ }^{38}$ (The term is parallel to les Anglais as a term for the English.) The Wik-Way languages do not have wik for 'language' or way for 'bad/difficult'. The Wik-Way languages are difficult languages from a Wik Subgroup perspective (or indeed almost any perspective) because of their sound systems, even though their grammar is fairly typical of Cape York languages generally. The Wik Subgroup phonologies and phonotactic systems are much more straightforward. I do not know whether or not there was once an indigenous Wik-Way equivalent of Wik-Way, although Winda-Winda may have been an approximation (see further discussion, Chapter 5). 
Although some degree of integration between Wik Subgroup and WikWay people has long been the case around the Archer River region, and older people from there were in the past systematically bilingual in both Wik Subgroup and Wik-Way types of language, the distinction has some continuing reality in people's minds. This is in spite of the fact that residential bases for some Wik-Way have been at Aurukun while others settled at Weipa or elsewhere, and the Aurukun-based Wik-Way people have lost all but a few fragments of their old languages (such as Andjingith, Linngithigh, and Alngith) and have adopted Wik-Mungkan as their first language of daily use. Some older Wik-Way people are competent speakers of other Wik languages also, such as Wik-Ngathan.

\section{Principles of succession}

Where an estate-owning clan has become extinct-an occurrence that is always a significant likelihood in a small-scale society where clans average about 25-35 members-it is normal for succession to the vacant estate to be activated by those with various pre-existing legitimate interests. Resolution of any particular case may take some years, perhaps decades, where it is contested. High on the list of pre-existing interests are having had a mother in the extinct patriclan group, especially if this structural factor is combined with other qualifications such as having a long history of personal association with the country in question, and knowledge of its place-names, stories, and resources.

Also high on the list, but of less power in debate, are connections to more distant antecedent holders of the estate (such as father's mother, or mother's mother), or the mere proximity of one's father's estate to the one falling vacant. Having a different language from that of the extinct clan appears to have been no barrier to succession, but any form of real distance-geographically, socially, genealogically—would pose great problems for anyone pretending to succeed to such an estate. Birthplaces and places of cremation or burial occasionally figure in arguments about the legitimacy of people's claims to land. However, these are site-specific forms of connection rather than estate-based ones, and they usually obtain just for the relevant person and their lifetime, and may not be transmitted to a succeeding generation. 
I observed over some decades an attempt by Alan Wolmby (Clan 6, Estate 6) to extend his personal connection to Ikeleth, a key site in an untenanted estate north-west of Aurukun where he was born in 1930, into a primary custodial relationship with the estate itself. In those days, a newborn was spiritually connected to a particular tree close to their birthplace by the afterbirth being customarily buried beneath that tree. Alan's attempt was not very successful, in spite of his community prominence and political acumen. In a later attempt, after Alan's death, his son Rexie Wolmby tried to use his father's birthplace as leverage for his own expression of interest in the Ikeleth estate (Estate 57, Lower Ward River). Lifetime individual rights in a site did not translate licitly into descent group succession to a whole estate, and Rexie's attempt failed.

When I first visited the area of Thoekel (Lower Love River, Estate 1) in 1974, the last patriclan members (Clan 1) had passed away and the estate was up for succession. The main contenders were the Peinkinna branch of the upper Love River (Estate 2, Clan 2), and the offspring of Carlippe, one of the last Thoekel patriclan members. The Peinkinna argument was based primarily on immediate proximity of estates on the same drainagethey were 'all one river'. The Walmbeng siblings for whom Thoekel was mother's and mother's father's country (also that of their MZ and MB and MFZ and MFB) had their own patriclan country (Estate 8, Warpang) quite a distance away and just inland from Cape Keerweer, so their case was based on immediate descent and not on proximity of patri-estate. Over roughly two decades, the succession was debated and disputed, until eventually it was settled in favour of the Walmbengs. Blood, alongside Rex Walmbeng's force of character, eloquence, and political dexterity, had won out over proximity, drainage, and persistence.

\section{Adoption and incorporation}

Adoptions of individuals may result in a child having two paternal ties to country, one to that of the 'real father' and one to that of the adoptive or 'step-father'. It seems that the individual's life-history, and the choices they may make when older, may affect which of the two gradually becomes dominant. 
There are two cases of incorporation of families, rather than adoption of individuals, into clans among the Wik. In one case, ${ }^{39}$ a family that originated in the Nicholson River region in the NT/Queensland border area became integrated into Wik society beginning in 1941, after being brought there by missionaries who were also bringing some Bentinck Island people to Aurukun (MacKenzie 1981:94), and they were granted customary land rights in the area of Uthuk Aweyn and Uthuk Eelen, also known as Watha-nhiin (Estates 4 and 3). They have retained an interest in their ancestral Nicholson River land, at least among the upper generations, and were successful claimants in the Nicholson River land claim in the early 1980 s. $^{40}$

A small number of non-Aboriginal individuals, including myself, have also been incorporated as kin into particular Wik families and are locally regarded as clan members with estate rights similar to those of their fellow clans-people, possessing the same totems and the same clan dialect, but none of them were native title applicants in the Wik case. Had they been so, they probably would have been legally excluded from recognition on the grounds of race.

\section{Shifts in the mode of reckoning descent of tenurial interests}

The descent system, as far as country affiliations go, has been modified since the 1970s in a slow process of transformation, so as to be open to cognatic rather than purely unilineal descent. ${ }^{41}$ Cognatic descent recognises descent group membership where the entry point is filiation to either parent, not just the father or just the mother.

In the 1990s, recruitment to country groups by patrifiliation, the classical ideal, was still strong among the Wik peoples, but a post-colonial pattern had by then also emerged.

39 For the other case see Appendix 2: Estate 5.

40 See Aboriginal Land Commissioner (1984:42-3); Denny Bowenda of Aurukun was listed there as Danny King, as his father was King Bowenda, and he was known by either surname, depending on location.

41 For discussion of this type of transformation, which in many parts of Australia is more advanced than it is in the Wik Region, see Sutton (2003:206-31). 
At that time a small but increasing number of children were taking their primary country affiliation from their mothers, at times, under the aegis of a powerful mother's father or mother's mother who was able to prevent the primary identification of their descendants shifting outside their own group.

The relationship between official surnames and country became more complicated. In the preceding decades of mission history there was a simple rule for the assignment of surnames: children took the surname of their father, and he was normally legally married to the mother, who herself also took her husband's surname upon marriage. In those decades there was a consistent relationship between the surnames recorded by mission staff and the patrilineal clan groups and therefore countries.

The system of surname allocation appears to have begun to apply to people reaching marriageable age, and their offspring, after about 1930 . This is consistent with the extreme likelihood that it was a system devised and imposed by Rev. William MacKenzie 1897-1972 (Wharton 2000). MacKenzie ran Aurukun Presbyterian Mission from 1923 to 1965 as superintendent, with his wife Geraldine MacKenzie as matron and school teacher (Cruikshank and Grimshaw 2015). When the MacKenzies arrived, people often had both 'bush names' (i.e. totemic names, ${ }^{42}$ also nicknames) and English ones (including words for animals such as Cockroach, Bandicoot, and Cockatoo, or descriptors like Wildfellow and Shortfellow and 'Left-hand' pronounced 'Lapan'), but had not as yet adopted a European first name/surname system.

What became Wik surnames during the 1920s and 1930s were largely a rendering by mission staff of one of the pre-existing totemic names of male members of particular clans. ${ }^{43}$ These totemic names were typically oblique and poetic references to totems held by the clan. Since men in the same clan shared more than one such name, there were sometimes several different surnames recorded, more or less by accident, for members of a single clan, including siblings. This added further complications. For example, the Landises (with a European-derived surname) were of the same clan (Clan 15) as Gothachalkenins and Eundatumweakins. Actual siblings in this clan included people with different surnames, such as the brothers

42 Those recorded are listed under each clan in Appendix 1.

43 Thomson (1946) gave a pioneering account of the Wik Subgroup naming system for people and dogs. In Appendix 1, the clan totemic names recorded for women, men, male dogs, and female dogs are listed. 
Billy Landis, Rupert Gothachalkenin and Bob-Wallace Eundatumweakin, all sons of Billy Wildfellow and his wives. In classical terms, all Landis men, like all Gothachalkenin and all Eundatumweakin men, shared the names Ku'-thaach-elkenh ('Dog + Rising Breakers', 'Gothachalkenin' in mission records) and Ooentetham-weykenh ('Goes about on its belly', 'Eundatumweakin' in mission records), among others. These came from the fact that among their clan's many totems were Thaach ('Breakers') and Ngamel ('Flat-tailed Stingray'), a bottom-dwelling elasmobranch.

Billy Landis probably acquired his English surname at the government-run Palm Island penal Aboriginal settlement off the coast of Queensland near Townsville. Names derived from non-Aboriginal people (e.g. Mittaboy ('Mr Boyd'), Mitherropsen ('Mr Robertson'), and Mithedaya ('Mr Dyer')) were not a large proportion of Wik names, and were used as first names in these instances, or as surnames in the cases of Lawrence, Kepple, Parker, and Day. Wik surnames derived from river names include Kendall, Holroyd, and Edward. Sometimes a forebear's first name would become the surname for his descendants, as in the case of the George, Fruit, Blowhard, Jingle, John, Matthew, and Shortjoe families.

Occasionally a clan's men shared a totemic name with men of a different clan and, as a result, in the mission period there developed pairs of clans sharing the same surname but holding different estates and, in most cases, being affiliated to separate languages. These include the pairs Yunkaporta (Clans 12 and 20), Pootchemunka (Clans 9 and 14), Owokran (Clans 60 and 82), Peemuggina (Clans 6 and 19), Koonutta (Clans 10 and 90), Woolla (Clans 22 and 31), and Yantumba (Clans 28 and 130). There are also, for example, four distinct Wik clans sharing the English settler name Kepple (see Clans 69, 75, 116, and 117), and two sharing the river name Edward (Clans 129 and 144).

Some people, when travelling outside the Wik world, would alter their names, perhaps to make it easier for others to pronounce them. For example, Francis Yunkaporta called himself 'Frank Porter' when 'outside' (an yoon, Wik-Mungkan), and Eembinpawn Gothachalkenin called herself 'Betty' when in Cairns Base Hospital. Mrs Geraldine Kawangka sometimes called herself 'Miss Geraldine' when in the city of Cairns.

Women of a particular clan also shared a set of traditional female names that were different from the male names. In classical times, women kept their own names for life and did not change them upon marriage. During 
the mission period, women's names, but not men's, were sometimes reduced to key letters, such as 'K.O.' for Kornamnayuh, or 'M.K.' for Mikompa.

By the 1960s, the MacKenzie-era surnaming system had been stable for several decades, and the relationship between surname and clan country had been stable for the same period. From the late 1960s onwards, however, the surname/clan relationship began to destabilise.

Table 3.2 summarises the surname system shift between 1960 and 1987 of those born at Aurukun. This table is derived from data in Sutton (2017). The figures in parentheses are the number of non-Aboriginal fathers in the sum. There were no non-Aboriginal birth mothers in the data. In two cases children were given surnames of both parents; these were both cases of a European father and Wik mother who were in a stable relationship.

Table 3.2: Shift in surnaming of babies, Aurukun 1960-87

\begin{tabular}{|l|c|c|}
\hline Birth year & Child takes F surname & Child takes M surname \\
\hline 1960 & 11 & 0 \\
\hline 1961 & 26 & 0 \\
\hline 1962 & 15 & 0 \\
\hline 1963 & 20 & 0 \\
\hline 1964 & 19 & 0 \\
\hline 1965 & 18 & $1(1)$ \\
\hline 1966 & 24 & 0 \\
\hline 1967 & 20 & 2 \\
\hline 1968 & 28 & 4 \\
\hline 1969 & 23 & 5 \\
\hline 1970 & 19 & 7 \\
\hline 1971 & 19 & 15 \\
\hline 1972 & 23 & $11(2)$ \\
\hline 1973 & 16 & $11(1)$ \\
\hline 1974 & 10 & 9 \\
\hline 1975 & 12 & 24 \\
\hline 1976 & 7 & $10(1)$ \\
\hline 1977 & 8 & $15(2)$ \\
\hline 1978 & 10 & \\
\hline
\end{tabular}




\begin{tabular}{|l|c|c|}
\hline Birth year & Child takes F surname & Child takes M surname \\
\hline 1979 & 8 & $18(2)$ \\
\hline 1980 & 3 & 11 \\
\hline 1981 & 10 & $17(2)$ \\
\hline 1982 & 1 & 22 \\
\hline 1983 & $5(1)$ & 14 \\
\hline 1984 & 0 & 6 \\
\hline 1985 & 1 & 24 \\
\hline 1986 & $1(1)$ & $20(1)$ \\
\hline 1987 & $3(1)$ & $22(1)$ \\
\hline
\end{tabular}

It follows from this table that in the years 1960-64 (as for some decades previously) no child had a surname other than its father's. By 1976, surnames for children derived from their mothers had become the predominant pattern. From being patrilineal, surnames had become matrilineal, in a remarkable transformation of practice by members of a younger generation. Estate assignment for children did not become matrilineal but cognatic in base and increasingly optative (choosing which parent or grandparent to follow for country identity). In the years 1967-72, mothers giving their babies their own surname were aged between 17 and 24 and having their first child. Married couples who had been having offspring before the departure of MacKenzie in 1965 continued to surname new children after their fathers, well into the new era (Sutton 2017).

What caused this dramatic shift? Here I am concerned to deepen the causal analysis I made in Sutton (1997a). At that time I considered the triggers for these changes to have been the decrease in stable marriages, and in fact the virtually complete disappearance of any new formal marriages once the MacKenzie era ended; ${ }^{44}$ an increase in the number of different men fathering the children of any one woman; men also having children with multiple partners; the emergence of children fathered by nonAboriginal men; and the increased financial independence of mothers. While generally I retain this analysis now, in fact, as Table 3.2 shows, the number of children fathered by non-Aboriginal men was only ever a tiny proportion between 1965 and 1987. Mother-surnamed children conceived with Aboriginal fathers totally outstripped in number

44 David Martin (1993:321-27) provides figures on the collapse of formal marriages at Aurukun. 
those conceived with non-Aboriginal fathers from 1967 to 1987. Non-Aboriginal paternities were not, as it happens, a primary driver of change in the allocation of surnames.

To those factors I would now add specifically the introduction of the single-parent pension, which occurred in 1973 and gave women more independence; the decline of the power of Wik patriarchy; the decline and fall of the mission patriarchy; and the increasing liberation of women, including their newly independent travel to the public towns of Weipa, Coen, and Cairns. The major shift in Wik surnaming practices occurred between the end of the 42-year MacKenzie domination regime in 1965 and the arrival of full-blown mission liberalism in about 1974.

Here I examine some of the fine-grained record that sheds some light on the initial change period, which can be fairly precisely located in the five years 1968-73. I have anonymised references to individuals but their names are in my unpublished records.

During the MacKenzie era and shortly afterwards, extramaritally conceived children with Indigenous fathers presented the surname allocation issue to people and it was dealt with in several ways. Recognition of the status of such children was not new. 'Steal-piccaninnies' and 'outside blanket' babies were long recognised by Wik people and there are cases on the record going back well past the MacKenzie surname era to bush times. Openly acknowledged extramarital paternity and actual versus social fatherhood were embedded in traditional practice and language. For example, Wik languages distinguish 'begetter' from 'upbringer', as in Wik-Ngathan wunypenh and Wik-Mungkan wunpan ('begetter'), as distinct from Wik-Ngathan thawan and Wik-Mungkan emathan ('upbringer'). ${ }^{45}$

Cases of births resulting from extramarital relationships during the MacKenzie era and just afterwards include the following. In 1955 a W-surnamed woman had a son by a Yam Islander and the boy was given the mother's married surname (i.e. her husband's). In 1956 a W-surnamed young woman (unmarried) gave birth to a son by a married Wik man, but the child was assigned the surname of the man its mother soon married,

45 Thomson (1936) presented cogent evidence gathered in the field in 1933 that Wik tradition recognised the biological role of the genitor in reproduction. 
not that of the publicly acknowledged genitor. The child continued to be identified at least as much with his genitor's country as with his pater's but always bore his pater's surname.

In 1967 a P-surnamed unmarried woman gave birth to a child she had to a married Wik man, and the child was assigned her surname not the father's. In 1968 a K-surnamed woman had a son by a married Wik man, and again the boy was given his mother's surname not his father's. In 1972 a P-surnamed unmarried woman had a daughter by a married man and again the daughter received her mother's surname not the father's.

Non-Aboriginal fathering of Wik children basically began in the late 1960s, although there were rare instances before then. For example, in about 1915, YG (c. 1899-1982) gave birth to her first child, a daughter conceived with a European man. She told me this in 1976. The baby did not survive long.

The next child born to a Wik mother and non-Aboriginal father, in my records (Sutton 2017; there may have been others), was LG, the first of her mother's children, who was born in 1965. She was given the surname of her mother. Next in the records was the first child of SO, born in 1970. She was to have four children born 1970-78. Apart from the case of her first child, the genitors were all non-Aboriginal and she never named any of them on the birth records, and all four offspring were allocated her own surname.

In 1972 a T-surnamed woman had a son by an unrecorded nonAboriginal man and the boy was given his mother's married surname, i.e. her husband's. In the same year, a W-surnamed unmarried woman had a son by an unrecorded non-Aboriginal man and the son took her own surname. She had three further children by non-Aboriginal fathers; these also took her surname but one was known by his father's as well as his mother's.

These two women were among the elite intelligentsia of Aurukun, highly astute, literate, excellent speakers of English in addition to their Aboriginal languages, and very assertive. A C-named woman, who was also in the same elite-intelligentsia group of young women of that era, had children with non-Aboriginal men in the 1980 s, one child taking her surname and another taking the father's. 
The years 1970-72 were a crunch point in social and cultural change in Wik society, though the pattern started to change by the mid-'60s. It was only after MacKenzie left in December 1965 that people were free to visit towns like Cairns as individuals, of their own volition. This journey to what locally is called 'the outside' represented sophistication and liberation as well. It is no surprise that it was culturally mobile, talented and assertive young women who made the break, and that in many cases they conceived with non-Aboriginal men while in Cairns.

The year 1965 was also the last of MacKenzie controlling lives at Aurukun with an iron fist. In the early 1960s, he and his wife Geraldine defied the order of the Presbyterian Board to close the Aurukun dormitories, and teenage girls and boys continued to live in separate dormitories controlled by the mission staff until immediately after the end of the MacKenzie regime (MacKenzie 1981:202). As a rule, girls transited rapidly from dormitory to wedding, under the MacKenzie regime's apparatus for preventing sexual misbehaviour.

The Presbyterian Church (from 1977 the Uniting Church) liberals who replaced MacKenzie and immediately closed down the dormitories were soon trying to devolve decision-making power to the people. And the new regime did not control people's marriages nor their movements in and out of Aurukun as their predecessors had done.

The aeroplane was as much a game changer for Aurukun-based Wik people as the camel had been for the Yankunytjatjara of Central Australia. Aurukun in the MacKenzie years was terribly inaccessible in the dry season and only accessible by air or boat in the long wet and post-wet flooding seasons. And MacKenzie kept it socially isolated too, by expelling unwanted visitors and being reluctant to allow Aurukun inmates to travel to any other centres except when on contract work approved of and usually arranged by the mission.

The first aircraft to land at Aurukun did so on 28 January 1941 (MacKenzie 1981:91-2). Regular mail plane visits to Aurukun from Cairns, operated by bush pilots, seem to have begun in $1962 .{ }^{46}$ As late as early 1967 these flights occurred only twice a month. In August 1967 the frequency was doubled to weekly. ${ }^{47}$ From the late 1960 s on, the archival sources include names of Wik passengers in increasingly substantial numbers.

46 AIATSIS MS1525/4, item \#80, 'Bush Pilots 1962-1975'.

47 AIATSIS MS1525/1, item \#15. 'Aircraft movements, landings 1966-1975'. 
Without this kind of fine detail, one is justifiably wary of broad-brush statements about social change and its causality. Here one can, with the aid of the daily records meticulously kept by the mission, piece together a complex process as it unfolded in incremental stages. In short, the shift away from patriliny was happening in the late 1960s along with a (minor) shift to non-Aboriginal paternity but not because of it.

The end of the MacKenzie regime was also the effective end of newly contracted formal marriages at Aurukun, although I think I have seen photos of weddings from as late as maybe 1972. Apart from a momentary revival in 1976 (when a kind Reverend unwittingly married an underage girl from Groote Eylandy to a local Wik man, an attempt by the Groote family to do a dynastic manganese royalty-retaining marriage), as far as I know there were no formal marriages until perhaps the early 2000 s when somebody revived the custom in the form of a church wedding. On a visit to Aurukun at that time I was taken to be introduced to the groom because he was such a curiosity, and regarded as almost a freak.

The end of formal marriage meant not only no wedding ceremony but a departure from the old cross-cousin partnering rules by many, an explosion of promiscuity, and serial cohabitation — 'just living' as they said—but also many stable de facto partnerships. Under MacKenzie, sexual behaviour was carefully monitored and misdemeanours noted in the mission diary and punishment delivered, sometimes in ways now quite illegal. These included shaving a woman's head and chaining her to a public tree.

While William MacKenzie was Superintendent of Aurukun 1923-65 he ruled with severe control. He knew that marital and extramarital relationships were the most common focus of conflict in Wik social life and its most common daily cause. He required proposed marriages to be discussed with him and he required the relatives of the couple to make formal agreement with the union before it could take place. In most cases the relatives signed the written agreement or, when illiterate, put an X identified as their mark, with Bill MacKenzie usually signing off himself so as to make the agreement fully formal. These were not marriage certificates - those were separate, typewritten statements or printed forms that were filled in at the time of the wedding and were held in a different mission file.

By the time of his retirement in 1965, MacKenzie had significantly broken the formerly massive powers of the Wik gerontocracy, through quelling spear fighting, physically challenging and fighting or thrashing 
men who resisted him, incorporating men into the mission hierarchy, and countless other measures, documentary evidence for which is plentiful. Paralleling the decline of Wik male authoritarianism was the decline of male authoritarianism in the Presbyterian Church. After MacKenzie, the new guard in the church were leaning over backwards to be kind and nice, a great contrast to the man who fitted the model of the 'policemanmissionary, with a gun in one hand and a Bible in the other' (Chaseling 1957:22). MacKenzie's kindness was sternly paternal, effective in saving lives but at the expense of Wik autonomy. At times he was very brutal.

I do not wish to imply that these changes only occurred because MacKenzie's rule ended and women were becoming economically independent. A shift away from formal marriage and the bestowal of fathers' names on children, towards de facto and other relationships in which children were increasingly bestowed with their mothers' surnames, was happening at the same time in Australian and Western society generally. The shifts I describe here were in part a result of the end of Aurukun's extreme isolation, both physically and culturally. 
This text is taken from Linguistic Organisation and Native Title: The Wik Case, Australia, by Peter Sutton and Ken Hale, published 2021 by ANU Press, The Australian National University, Canberra, Australia.

doi.org/10.22459/LONT.2021.03 